\title{
The Taravilla Lake and Tufa Deposits (Central Iberian Range, Spain) as paleohydrological and paleoclimatic indicators
}

B.L. Valero Garcés ${ }^{1}$, A. Moreno ${ }^{1}$, A. Navas ${ }^{2}$, P. Mata ${ }^{3}$, J. Machín $^{2}$, A. Delgado Huertas ${ }^{4}$, P. González Sampériz ${ }^{1}$, Antje Schwalb ${ }^{5}$, Mario Morellón ${ }^{1}$ and Larry Edwards ${ }^{6}$

1 Instituto Pirenaico de Ecología (C.S.I.C.), Apdo 202, 50080 Zaragoza, España, blas@ipe.csic.es, amoreno@ipe.csic.es, pgonzal@ipe.csic.es, mariomm@ipe.csic.es

2 Estación Experimental de Aula Dei (C.S.I.C.), Apdo 202, 50080 Zaragoza, España, anavas@eead.csic.es, jimac@eead..csic.es

3 Facultad de Ciencias del Mar, Universidad de Cadiz. Puerto Real, 11510 Cadiz, España, pilar.mata@uca.es

4 Estación Experimental de El Zaidin (C.S.I.C.), Prof. Albareda 1, 18008 Granada, España, antodel@eez.csic.es

5 Institut fur Geowissenschaften,Technische Universitat Braunschweig,Pockelstrasse 3Braunschweig D38106, Germany, antje.schwalb@tu-bs.de

6 Department of Geology and Geophysics, University of Minnesota, Minneapolis, MN-55455, USA edwar001@umn.edu

Keywords: Holocene, lake, paleoclimate, karstic, tufa, stable isotope, Spain, Mediterranean 


\section{ABSTRACT}

Lacustrine and tufa records from Laguna de Taravilla (Iberian Range, Guadalajara province, Spain, $40^{\circ}$ $39^{\prime} \mathrm{N}, 1^{\circ} 59^{\prime} \mathrm{W}, 1100 \mathrm{~m}$ a.sl.) have been analyzed using sedimentological, mineralogical, geochemical and palynological techniques. A preliminary chronological framework is based on $\mathrm{U} / \mathrm{Th},{ }^{14} \mathrm{C}$ AMS, ${ }^{210} \mathrm{~Pb}$ and ${ }^{137} \mathrm{Cs}$ dates. The lacustrine-tufa system developed in a hanged tributary valley of the Upper Tajo River and it is composed of a large perched springline tufa building, and barrage tufa dam that impounds the small Laguna de Taravilla (2.1 ha surface area, $11 \mathrm{~m}$ maximum water depth). The Taravilla tufa stable isotope compositions are similar to other examples in central and southern Spain and they plot in the same field of the other lowland European stream tufas. These values are coherent with the range of isotopic compositions measured in the Taravilla spring and lake water, and provide useful paleoenvironmental information. Facies analyses shows that clastic depositional processes are dominant in the Taravilla Lake. Fining upward sequences and sands and coarse silts reflect periods of increased alluvial activity of the inlet. The dominance of clastic depositional processes and the input of detrital carbonate hinder the use of lake mud stable isotopic compositions as environmental indicators. Phases of increased travertine growth occurred during the Late Pleistocene (Last Glacial to Interglacial transition from oxygen isotopic stage 6 to 5) and during the Lateglacial and Early Holocene. Although the Taravilla chronology does not allow a detail analysis of flood frequency, the reconstructed evolution is coherent with the palaeoflood history of the Tajo River for the last 2000 years, particularly with an increase during the last 500 years. The increase in flood frequency coincides with other evidences of wetter and colder climate and environmental change in Central Spain and in Europe during the Little Ice Age. 


\section{INTRODUCTION}

The headwaters of the Tajo River in the Serrania de Cuenca (Iberian Range, Central Spain) is one of the largest karstic regions in Spain, with numerous lakes, tufa deposits, and surface karst features. The karstification of the Mesozoic carbonate formations in the region started during the Upper Pliocene - Lower Pleistocene (Gutiérrez-Elorza and Peña Monne, 1975, 1979: IGME, 1989), and although currently it is mostly inactive, the regional hydrogeology is mainly controlled by karstic water circulation. Tufa deposits related to spring and fluvial activity and lacustrine sediments are common in karstic systems, and they are among the best terrestrial archives of past environmental and climate changes (Ordoñez et al., 1986, Pedley, 1993; Vadour, 1994; Sancho et al., 1997; Taylor et al., 1998; Gedda et al., 1999; Andrews et al., 2000; Peña et al., 2000). Tufa deposits are located at water discharge areas of karstified limestone aquifers providing carbonate-rich waters. The development of tufa constructions associated to karstic systems is controlled by geology (carbonate terrains), topography (presence of steps in the valley, changes in the river dynamics altering water outgassing), hydrology (Karstic aquifers, occurrence of springs), hydrochemistry (carbonate and calcium-rich waters) biology (moss and other plants activity that induce precipitation of calcite) and climate factors (see reviews in Goudie et al., 1993, Chen et al., 2004). Perched springline tufas have been described in several tributaries of the Tajo River (Ordoñez and González Martín, 1979; González Martín et al., 1989; Ordoñez et al., 1990; Pedley et al., 2003). Nearby the Taravilla lake, both perched and fluvial tufa occur in the Tajo River valley (Guerrero Domínguez and González-Martín, 2000). Ecological and hydrological surveys and studies of short sediment cores from the "torcas" (sinkhole lakes) of Cañada del Hoyo (Cuenca) have also shown the high sensibility of the karstic systems to limnological, anthropogenic and climate changes ( Miracle et al., 1992; Rodrigo et al., 1993; Burjachs, 1996; Mezquita and Miracle, 1997; Julia et al., 1998).

In this paper we analyze the Taravilla karstic and tufa system ( $40^{\circ} 39 \mathrm{~N}, 1^{\circ} 59 \mathrm{~W}, 1100 \mathrm{~m}$ a.s.l) and explore its potential and shortcomings as environmental and climatic archive. The system contains examples of three of the four end members of the continuum of depositional bedforms and environments of tufa formation proposed by Pedley (1990) and Ford\& Pedley (1996): fluvial barrage, lacustrine and perched springline tufas. A fluvial barrage tufa consisting of a $30 \mathrm{~m}$ high and $100 \mathrm{~m}$ long arcuate dam impounds the Laguna de Taravilla within a relatively narrow hanged valley, tributary of the Tajo River. On the southern slope of the tributary valley, a perched springline tufa system occurs. Two phases of tufa construction have 
been identified and some preliminary dating is available using $\mathrm{U} / \mathrm{Th}$ series techniques. Several sediment cores retrieved from the Taravilla Lake have been dated with ${ }^{14} \mathrm{C}$ AMS and analyzed using a multiproxy approach including magnetic properties, sedimentology, geochemistry, stable isotopes, palynology and ostracod content. Sedimentary facies analyses show the dominance of detrital processes in the lacustrine depositional system and suggest the potential of the sequences as paleoflood records.

\section{STUDY SITE}

\section{Physical setting}

The Upper Tajo River valley is located in the Serrania de Cuenca, in the Western Branch of the Iberian Range. The regional geology is dominated by Mesozoic (Jurassic and Cretaceous) carbonate formations overlying clastic Triassic formations and folded and fractured during the Alpine orogeny. The relief is mostly structural, with crests, cuestas and flat-topped hills. Some flat areas are interpreted as remains of a paleorelief developed up to the Middle Pliocene (IGME, 1989). Karstification of the Cretaceous carbonate formations started during the Upper Pliocene but currently it is mostly inactive (Gutierrrez-Elorza et al., 1975, 1979). Surface karstic morphologies are common, and also sinkholes, dolines, and poljes. The Tajo River excavated deep gorges in the Upper Cretaceous dolomite formations during the Quaternary. Clastic slope accumulations are common in the slopes of the cliffs related to intense periglacial activity during the last glacial period. In the Taravilla area, tufa deposits occur in the Tajo River valley fllor, in several slopes, and associated to springs (IGME, 1989, Guerrero Domínguez and González-Martín, 2000). The regional hydrogeology is essentially karstic. The Upper Cretaceous carbonate formations constitute the main regional aquifer; most springs are located at the contact with the underlying less permeable Jurassic formations, as is the case with the Taravilla spring that feeds the lake and the tufa structures. The Taravilla Lake and tufa buildups occur in a small hanged tributary valley of the Tajo River located in an area where the underlying Jurassic formations crop out along dominant NNW-SSE tectonic faults (Fig. 1)

The regional climate is of Mediterranean type with strong continental influence; winter temperatures are low (average December and January temperature lower than $0^{\circ} \mathrm{C}$ ), summers are short and relatively warm (average August temperature $20^{\circ} \mathrm{C}$ ). Average annual rainfall is about $560 \mathrm{~mm}$, although inter annual variability is large. May and June are the wetter months, and July and August the driest. Rainfall is controlled by the westerlies, associated with cold fronts during the springs, and some rain shadow effect due to the location in the eastern slope of the Iberian Range. During the summer the subtropical Azores anticyclone 
blocks moisture availability from the west. Almost $75 \%$ of the area is forested, and the vegetation corresponds to the supraMediterranean subhumid type (Peinado-Lorca and Martínez-Parras, 1987). Pine is dominant (more than half of the total surface of the Upper Tajo River Natural Park), but there are also some patches of Juniperus thurifera, Quercus rotundifolia and Quercus faginea.

\section{Limnology and hydrology}

The Taravilla Lake has a 2.11 ha surface area and $11 \mathrm{~m}$ of maximum water depth (Fig. 2). It is mostly groundwater-fed. Only one permanent spring occurs in the eastern margin at lake level although most likely there are more underwater springs. During wet periods, the springs related to the tufa buildup in the eastern margin and located at middle slope altitude are also functional. The northeastern creek drains a large watershed, but the inlet is only functional during wet periods. The only outlet, located at the southeastern margin of the barrage tufa, drains the Laguna de Taravilla waters into the Tajo River, and becomes nonfunctional during dry periods. The lakewater has a $\mathrm{pH}$ value of 7.8 , intermediate between the spring values (7.5) and the Tajo River (8.25). Conductivity has similar values in the spring, lake and river (mean value of 0.5 $-0.6 \mathrm{mS} / \mathrm{cm})$. The lake and spring waters are calcium and carbonate -rich, with some seasonal variability, but very similar in composition. Most common ions present in the lake waters and spring waters are: $\mathrm{Ca}^{2+}$ : $39.4 \mathrm{mg} / \mathrm{l}, \mathrm{Mg}^{2+}: 28.2 \mathrm{mg} / \mathrm{l}, \mathrm{Na}^{+}: 3.03 \mathrm{mg} / \mathrm{l}, \mathrm{K}^{+}: 0.3 \mathrm{mg} / \mathrm{l},{ }^{-} \mathrm{HCO}_{3}: 3.11 \mathrm{mg} / \mathrm{l}, \mathrm{SO}_{4}{ }^{2}: 0.06 \mathrm{mg} / \mathrm{l}$, and $\mathrm{Cl}^{-}: 0.31 \mathrm{mg} / \mathrm{l}$. The Tajo River waters contain less $\mathrm{Ca}^{2+}$ and $\mathrm{Mg}^{2+}$, and more $\mathrm{Na}^{+}$, indicating higher rates of Cretaceous dolostones dissolution in the springs and higher input of salts derived from the Upper Triassic outcrops in the river waters. The $\delta \mathrm{H}$ and $\delta^{18} \mathrm{O}$ values of the lake and the spring waters are very similar to the Tajo River and all of them plot in the meteoric water line (Fig. $3 \mathrm{~A}$ and B) indicating little evolution from the regional meteoric waters and no evaporative effects. Lake waters are chemically and isotopically well-mixed. Lake and spring waters are relatively enriched in ${ }^{18} \mathrm{O}$ and depleted in ${ }^{13} \mathrm{C}$ compared to the Tajo River (Fig. 3), reflecting the different compositions of local groundwaters and regional meteoric waters.

\section{METHODS}

The Laguna Taravilla watershed was identified and mapped using topographic and geological maps. The tufa formations were mapped and the main facies were described and sampled. A seismic survey was conducted with a 3.5 Khz seismic profiler in June 2002 (Fig. 4). Sediment penetration was poor, likely caused by the presence of gas, as result of organic matter decomposition. In 2001 and 2002 sediment cores were retrieved in the littoral (core C, $4 \mathrm{~m}$ water depth) and central areas of the lake (cores A1, A2 and B, $11 \mathrm{~m}$ water depth), just behind the tufa barrage, using a modified Livingstone piston corer. One of the cores was 
sub-sampled in the field at 0.5 and $1 \mathrm{~cm}$ intervals for ${ }^{210} \mathrm{~Pb}$ and ${ }^{137} \mathrm{Cs}$ dating. A $2 \mathrm{~m}$ long core was taken in the palustrine area closer to the water inlet (Core D). Three new longer cores (TAR04-1A, 2A and 3A) were obtained from the deeper central area in Spring 2004 by a modified Kullemberg piston coring platform from the Limnological Research Center, University of Minnesota (USA). Magnetic susceptibility was measured with a Bartington magnetic susceptibility bridge every $2 \mathrm{~cm}$ in core A1 and in the three longest cores every $\mathrm{cm}$. The 2004 cores were imaged with a DMT Core Scanner. All Taravilla cores were split in two halves and sedimentary facies were defined by macroscopic visual description including color, grain-size, sedimentary structures, fossil content, and by microscopic smear slide observations (Schnurrenberger et al. 2003). Taravilla A, B and D cores were sub-sampled for organic matter, carbonate, grain size, mineralogy, trace element and isotope geochemistry, pollen, and ostracodes and the long TAR04-1A-1K was sampled every 5 $\mathrm{cm}$ for organic matter and carbonate content. In cores A, B, and D, organic matter content was determined by loss-on-ignition analyses at $450^{\circ} \mathrm{C}$ (Heiri et al. 2001) and carbonate content with a Barahona calcimeter (CSIC 1976). Although LOI is not an accurate standalone technique for the estimation of the carbon content (Santisteban et al. 2004; Boyle 2004) it provides a useful characterization of the sediment composition and the sedimentary facies. Total carbon, total sulfur and organic carbon contents were analyzed on TAR04-1A$1 \mathrm{~K}$ core with a LECO SC 144DR elemental analyzer. Whole sediment mineralogy was characterized by X-ray Diffraction, and relatively mineral abundance was determined using peak intensity. Grain size was determined using a Coulter particle size analyzer (Buurman et al. 1997). Samples were treated with $10 \%$ hydrogen peroxide in a waterbath at $80^{\circ} \mathrm{C}$ to eliminate the organic matter, a dispersant agent was added and ultrasound treatment was used prior to measurement.

Bulk sediment samples $(0.5 \mathrm{~g})$ were digested with HF (48\%) in microwave (Milestone $1200 \mathrm{mls}$ ). Analyses for main elements composition were performed by atomic emission spectrometry using an inductively coupled plasma ICP-OES with solid state detector (Perkin Elmer Optima 3200 DV).

Stable carbon and oxygen isotope compositions were carried out by mass spectrometry in bulk sediment samples and ostracods following standard procedures and using an IRMS Finnigan MAT 251. Ostracode valves were separated from 2-cm-thick slices taken every $20 \mathrm{~cm}$, following the procedure described by Forester (1988). The isotopic values are reported in the conventional delta notation relative to the PDB standard. After acidification of the samples with $\mathrm{HCl} 1: 1$, the $\delta^{13} \mathrm{C}$ on organic matter was measured by an Elemental Analyser Fison NA1500 NC. Analytical precision better than $0.1 \%$. Smear slides and XRD analyses were performed to check the presence and type of carbonate (calcite and dolomite) in the 
sediments. Pollen grains and spores were sampled every $10 \mathrm{~cm}$ in core B and extracted in the laboratory by the classic chemical method (Moore et al. 1991) using Thoulet dense liquid (2.0) for palynomorph concentration and Lycopodium clavatum spore tablets to calculate pollen concentration (Stockmarr, 1971).

The chronology for the lake sequence is constrained by $8 \mathrm{AMS}^{14} \mathrm{C}$ dates from several cores (Table 1 ) analyzed at the Arizona Dating Facility (USA) and the Poznan radiocarbon laboratory (Poland), and by ${ }^{210} \mathrm{~Pb}$ and ${ }^{137} \mathrm{Cs}$ dating in the core TAR-A1 performed at the St. Croix River Station (University of Minnesota) (Fig. 5). All cores were correlated using sedimentary facies, grain size, and organic matter profiles (Figs. 6 and 7). The chronology for the tufa deposits is derived from Uranium-Thorium disequilibrium analyses performed at the Minnesota Isotope Laboratory (Table 2).

\section{RESULTS}

\section{Chronology}

Total ${ }^{210} \mathrm{~Pb}$ activities in core A-1 are low (range between 0.87 and $1.7 \mathrm{pCi} \mathrm{g}^{-1}$ ), and fluctuate irregularly with no clear down-core trend (Fig. 5). A preliminary c.r.s. modeling of the Taravilla ${ }^{210} \mathrm{~Pb}$ data assuming that the lowermost 7 samples (below $13.5 \mathrm{~cm}$ ) with a mean ${ }^{210} \mathrm{~Pb}$ activity of $1.0 \mathrm{pCi} / \mathrm{g}$ represent supported ${ }^{210} \mathrm{~Pb}$, gives a ca 1950 age for the upper $10 \mathrm{~cm}$. Measurable radio-cesium was found at only one depth interval (8$8.5 \mathrm{~cm}, 0.427 \mathrm{pCi} / \mathrm{g}$ ) out of the nine analyzed between the core top and $77 \mathrm{~cm}$. As suggested by the ${ }^{210} \mathrm{~Pb}$ results, high sedimentation rates and subsequent dilution of the atmospheric ${ }^{137} \mathrm{Cs}$ signal is the most likely explanation for this pattern of non-detection. The presence of ${ }^{137} \mathrm{Cs}$ at $8-8.5 \mathrm{~cm}$ precludes the alternative explanation: a depositional hiatus during the last half-century. Assuming that the detection of ${ }^{137} \mathrm{Cs}$ at $8-8.5$ $\mathrm{cm}$ represented the 1963 peak in atmospheric nuclear testing, it would match the ${ }^{210} \mathrm{~Pb}$ chronology. However, this could be largely a coincidence because more than a single measurement are needed to define the ${ }^{137} \mathrm{Cs}$ peak, and the ${ }^{210} \mathrm{~Pb}$ chronological model is not very reliable. However, taking the ${ }^{210} \mathrm{~Pb}$ and ${ }^{137} \mathrm{Cs}$ data in consideration, both indicate very high sedimentation rates over the last century, with a mean sedimentation rate of at least $1.5 \mathrm{~cm} / \mathrm{yr}$ or $1.0 \mathrm{~g} \mathrm{~cm}^{-2} \mathrm{yr}^{-1}$ during the last half century.

The radiocarbon chronology of the longest core (TAR04-1A-1K) is based on three ${ }^{14} \mathrm{C}$ AMS dates, two of them on wood remains and the lower one on bulk organic matter. Four more dates on the previous cores help to constrain the age of the upper part of the sequence (Table 1). The Taravilla record spans the last 1600 years. Sedimentation rates are about $4 \mathrm{~mm} / \mathrm{yr}$ for cores $\mathrm{A} 2$ and $\mathrm{B}$. The date in core A-1 $\left(466 \pm 41{ }^{14} \mathrm{C}\right.$ yr BP) does not fit with the composite chronological model for all cores and the inferred sedimentation rate is too small compared with the estimated ${ }^{210} \mathrm{~Pb}$ and ${ }^{137} \mathrm{Cs}$ sedimentation rates from the same core. A possible 
explanation is that the age of the sample does not correspond with the age of the sediment, because old wood was reworked from the catchment and incorporated into the sediment. The sandy nature of the layer where the macrorest was sampled, favors this interpretation. The young age of the sample at $260 \mathrm{~cm}$ in core TAR04-1A-1K (340 $\pm 30{ }^{14} \mathrm{C}$ yr BP) is likely caused by contamination with younger carbon. This date has not been included in our chronological model. In spite of the chronolological uncertainties, the five AMS dates indicate that the lower sedimentary unit (about $2 \mathrm{~m}$ of laminated carbonate mud and silt, see below) deposited between the IV and XVI century, and the upper $4 \mathrm{~m}$ of the sequence deposited during the last 500 years. Although reworking of the dated sample in core $\mathrm{D}$ cannot be completely rule out, the date also shows a comparable high sedimentation rate in the palustrine areas.

Preliminary U/Th dating suggests that the main phase of construction of the Taravilla perched springline tufa is around $139.7 \pm 3.1 \mathrm{kyrs}$ (Table 2). The dated sample was a stromatolitic, well-lithified, non-porous, pure carbonate, with very low detrital Th contamination, and consequently, we consider the date as reliable. Two out of the five samples from the barrage dam had too high Th contamination $\left({ }^{230} \mathrm{Th} /{ }^{232} \mathrm{Th}\right.$ ratios) to provide reliable dates. The other two samples with lower Th contamination provided un-corrected ${ }^{230} \mathrm{Th}$ ages of $18.5 \pm$ 0.7 and $15.9 \pm 0.6 \mathrm{ka}$. Considering that contamination by detrital Th produces older nominal ages, the ages are most likely younger; the "corrected" ages are $8.8 \pm 5.2$ for the top of the barrage and $7.1 \pm 4.6$ ka for the middle. Taking all the dates in consideration and the uncertainties (Table 2), it seems that the construction of the barrage occurred between the lateglacial to early Holocene. Vegetal remains within the tufa in the middle area of the barrage provided an AMS age of $192 \pm 47{ }^{14} \mathrm{C}$ yr BP indicating tufa production has still being active in historical times.

\section{Sedimentology}

Perched springline tufas. The perched springline tufa of Taravilla is a composite buildup developed on the eastern slope of the valley covering a large area (approximately $500 \mathrm{~m}$ long, up to $35 \mathrm{~m}$ high, and almost $200 \mathrm{~m}$ wide at the top) between the NE inflow creek and the SE outlet of the Taravilla Lake (Fig. 2). The tufa buildup has the typical wedge-shaped, terraced, downslope-facing lobate profile. Two main terrace levels can be distinguished (Fig. 2). The upper surface of the upper terrace is rather flat; frontal areas towards the lake and close to the outlet are steeply steep; the lower terrace is gently convex. The length of the buildup and the variety of facies and morphologies reflect the complexity and composite nature of the deposits, with coalescence of adjacent springs and changing distribution through time. Currently, the tufa buildup is mostly non-functional. The springs located at higher altitude in the valley slope are usually inactive, and only during 
particularly wet periods feed the tufa and the lake. The main spring feeding the lake is located in the same area, at lower altitude, suggesting that the origin of the main point-sourced water is tectonically-controlled.

Meter-scale terraces and step topography occur in this formation. The facies are very diverse as it is common in these formations (Ford and Pedley, 1996; Martín-Algarra et al., 2003; Ordoñez et al., 2005). In the distal parts of the tufa lobe well-cemented bryophyte phytoherm framestones (Ford \& Pedley, 1996) with inclined internal fabrics alternate with subhorizontal tufa laminites developed in the shallow flights of pools behind the phytoherms steps. Finely laminated cascade facies are developed at the lobe margins. They are interpreted as fast growing moss-curtain facies. Finely laminated Stromatolite facies, with subhorizontal and inclined fabrics are common. Primary cavities also occur. The lobe-top terraces show flat to slightly convex surfaces and no pool facies development. The distal slope facies are not well-developped, indicating reduced dismantling of the phytoherms lobes. However, these facies could be covered by littoral vegetation or even submerged under the lake. The tufa buildups are well preserved because of the well-lithified fabrics and the early cementation that makes them resistant to erosion and compaction. Intraclastic tufa breccias recording periodic erosion are present, but not very common. In the distal areas, oncoid facies occur in some channels within the tufa buildup and also in the creek close to the lake.

Preliminary U/Th dating suggests that the onset of construction of the Taravilla perched springline tufa is around $139.7 \pm 3.1 \mathrm{kyrs}$. It seems likely that the deposits higher in the valley are older than those lower down the slope, as is the case in other examples in the Tajuña River (González Martín et al., 1989). Variations in water-table level and spring discharge lead to episodes of construction alternating with inactive phases and some dismantling. Falling watertables have likely resulted in the progressive downslope development of the Taravilla perched springline deposits.

Barrage (dam) deposits. A downstream - facing barrage is developed across the valley and holds back the Laguna de Taravilla. The barrage is $175 \mathrm{~m}$ long, about $75 \mathrm{~m}$ wide at the top and up to 275 at the bottom, and about $30 \mathrm{~m}$ high. The barrage is very broad in the direction of the flow with a wide crest and a large ramplike buttress of inclined tabular bedded tufa on the downstream. This morphology corresponds to the principal barrage type as defined by Pedley et al (1996). The maximum growth of the structure in the flow direction also suggests some similarities with phytoherm framestone prograding wedges described in slopes and fluvial settings (Guerrero Domínguez and González-Martín, 2000). The dominant fabrics in the barrage surface are phytoherms (both moss framework and stromatolitic) with some detrital tufa. Currently tufa formation is only active along the outlet that connects Laguna de Taravilla with the Tajo River. The outlet becomes dry during 
the summers but it overflows during wet seasons, flooding completely the barrage and spilling over the crest. The downstream side of the barrage is still well preserved and only in some areas has been partially trenched and undercut. There are no marginal stromatolitic terraces associated to the barrage as it occurs in some of the Ruidera barrage systems (Ordoñez et al., 2005).

The barrage tufa started to develop close to the thalweg knick point of the small tributary creek feeding into the Tajo River. Changes in the Tajo River dynamics may have been responsible for the onset of tufa deposition. As it has been shown in other Tajo River tributaries (Huertapelayo and Puente de San Pedro, González Amuchastegui \& González, 1993 and González Amuchastegui, 1998), the lowering of the Tajo River base level due to increased incision, creates a hanged tributary valley and generates a waterfall, conducive to tufa development. Primary barrages as the Taravilla one, show a major component of downstream prograding during their development. Five samples were dated with U/Th but because of detrital Th contamination the ages are not conclusive. Taking into account all ages, it seems that the construction of the barrage occurred between the lateglacial to early Holocene (Table 2).

\section{$\underline{\text { Lacustrine sediments }}$}

Behind the tufa barrage, a small lake develops, the Laguna de Taravilla. The lake does not have stromatolite-dominated lake margin constructions (lacustrine tufas) typical of other tufa-lacustrine settings. Two main depositional environments are distinguished in the Laguna de Taravilla: lacustrine and palustrine (Fig. 2A). The lacustrine depositional environment comprises a narrow littoral zone, very steep margins and a flat lake bottom. Thick aquatic vegetation overhangs at the edge of the lake, and some of the submerged plants are coated with carbonate, but no tufa deposition occurs in the littoral zone. The bottom of the lake is colonized by Chara vulgaris. (Molina, 1996). The thickness of the sediments fill in the Laguna de Taravilla is unknown, due to the poor penetration of the seismic survey (Fig. 4). The seismic survey shows the very steep SW margin of the lake at the barrage and a gentler NE margin connecting with the palustrine areas (seismic profiles $A$ and $B$ ). The tufa barrage facies show some subhorizontal seismic reflectors and other areas with no reflections, seismically massive. The northeastern margin of the basin shows several wedge-shaped morphologies and cross-cutting reflectors that could be interpreted as prograding sedimentary units (seismic profile C). Only the upper part of the sedimentary infill shows parallel - well defined reflectors, continuous all over the basin. Below 3-4 m, the reflectors loose the continuity and the penetration is very poor. Six cores allowed the description and interpretation of the sedimentary infilling of the Laguna de Taravilla. 
Core Facies. The Taravilla sedimentary record is composed of decimeter-bedded, massive to faintly laminated, brownish gray, carbonate sediments with variable amount of organic remains and several intercalated carbonate sandy layers. Five main sedimentary facies have been identified after integration of visual description, microscopic observations and sediment composition (Table 3). Facies 1, 2 and 3 are massive to faintly laminated carbonate mud, silt and sand with variable organic matter, carbonate and silicate contents. Carbonate fraction is mostly composed of calcite and dolomite grains and crystals. Calcite has a double origin, clastic and authigenic. Clastic calcite has also a double source, the Cretaceous rocks and the tufa buildups. The authigenic fraction is composed of euhedral 10-15 $\mu$ long crystals and charophyte remains. Dolomite is only detrital, derived from the dolomitic Upper Cretaceous formations. Grain size ranges from sand-size rounded grains and euhedral crystals to several hundreds microns long crystals. Clay minerals and quartz are also transported from the watershed (the middle Cretaceous clastic unit). Organic matter in the coarser facies (coarse silts and sands) is mostly composed of macrorests derived from the wetland and the watershed. Aquatic, amorphous organic matter is more common in the finer, darker facies. Coarse, sandy facies, contain abundant carbonate clasts -derived from the tufa buildups and also the dolomite formationsand large macrorests derived from the wetland and the watershed (wood, aquatic plants). Dolomite content is an indicator of clastic input into the Taravilla lake, marking intervals of decreased input (top $20 \mathrm{~cm}, 75-100 \mathrm{~cm}$ in core $1 \mathrm{~A})$ and higher input $(55-75 \mathrm{~cm})$.

Facies 1 are interpreted as coarser deposition during flood episodes reaching the center of the lake. At the top of the core, a distinctive $\mathrm{mm}$ thick reddish coarse silt and sand layer occur. Massive, lighter grey silt and mud (Facies 2) represent deposition in the Taravilla lake during periods of less strong alluvial influence, and open water circulation. Darker, massive to faintly laminated fine silt and mud (Facies 3) represent deposition during periods of lower energy, less fluvial influence, restricted water mixing, and occurrence of some periods with anoxic bottom conditions. Most of the clastic material transported into the lake is carbonate, so Facies 1 has the highest carbonate and dolomite content and, consequently, lower magnetic susceptibility values. Finer darker facies have higher clay mineral and quartz content and also higher magnetic susceptibility values. These three facies are arranged in decimeter to meter-thick fining upward sequences. Chemical indicators reflect mineralogical composition: higher Mg values in coarser facies with more dolomite, higher iron in finer facies with more clays (Fig. 5). Iron and aluminum are usually good indicators of soil erosion in the watershed (Boyle 2001), and the increasing trend in iron in core B could reflect 
increasing erosion from the watershed. However, this trend is not parallel by a similar trend in aluminum, which suggest that the iron record may be influenced by redox changes in the lake.

Facies 4 only occur in core $\mathrm{C}$, located at $4 \mathrm{~m}$ water depth behind the barrage tufa and it is characterized by the abundance of gastropods, mollusk and charophyte remains. Massive to faintly laminated, dark grey, organic -rich (up to $10 \%$ organic matter) carbonate silts alternate with massive, grey silts with more abundant gastropods and mollusks. These sediments represent littoral deposition mostly caused by reworking of the charophyte meadows and other carbonate-encrusted littoral formations.

Facies 5 is composed of finely laminated, light grey, fine carbonate silt and mud. They have relatively lower carbonate content and medium values of magnetic susceptibility. Sandy layers are absent. Facies 5 represents deposition in a lower energy environment, with less alluvial influence, as denoted by the lamination and lack of sandy intervals. This facies only appears in the lowest interval in the longest cores, alternating with cm-to dm thick layers of Facies 3 (Unit 4).

The Taravilla lake record has been divided in four sedimentological units (Figs. 6 and 7). The basal unit 4 is composed by laminated sediments (Facies 5 and Facies 3 ). Unit 3 is characterized by the dominance of darker carbonate silts in thick layers (Facies 3). Unit 2 encompasses a thick fining upward sequence composed of sands and silts. The top Unit 1 is characterized by an alternation of dm-thick layers of Facies 1 , 2 , and 3.

The palustrine environment. More than half of the surface area of the Taravilla basin is occupied by a palustrine, wetland environment (Fig. 2). The area is covered with thick vegetation and it gets flooded seasonally when spring discharge increases and the ephemeral inlet becomes active. The surface is covered with detrital tufa facies, particularly in the areas close to the inlet, where mixed deposits composed of material derived from slope wash of previous tufas and alluvial material from the Cretaceous outcrops in the watershed.

Core Facies. The almost $2 \mathrm{~m}$ long core $\mathrm{D}$ is composed of coarse clastic facies at the base (Facies 6), topped by organic-rich silts with some peat intercalation towards the top (Facies 7). Clastic facies 6 are gravels and silts, arranged in fining upward sequences. Gravel beds, up to $25 \mathrm{~cm}$ thick are composed of Cretaceous rocks fragments and tufa clasts with a carbonate and quartz sandy matrix. Coarse silts contain abundant plant remains. Facies 6 represents deposition in an alluvial-deltaic setting related to increased creek activity. The upper part of the core is composed of massive, organic-rich silts with some thin peat layer 
intercalations (Facies 7). Deposition of this facies reflects lower energy environments, in a wetland, palustrine setting. Deposition of the thickest and coarser gravel layer in core D (dated as $471 \pm 37{ }^{14} \mathrm{C}$ yr BP) could correlate with deposition of the thickest and coarser sand layer in the middle of the lake (Unit 2). The dating uncertainty in core TAR04-1A-1K impedes a definitive time-correlation. The onset of the wetland development occurred in the last few centuries (Fig. 7).

\section{Pollen.}

Pollen data from core B reflect a vegetation cover typical of the Mediterranean mountain areas, with little variations during the last centuries (Fig. 5). The main arboreal component is Pinus (60-80\%). Juniperus and Quercus faginea-pubescens type values range between $10-20 \%$ and Quercus ilex-coccifera type up to $10 \%$. The pollen assemblages reflect a regional forest mostly composed of Pine, with some deciduous oaks in the northern slopes, evergreen oaks and junipers in the sunny aspects, and mesophylous taxa (Corylus, Alnus, Betula, Salix, Ulmus, Tilia, Fagus, Populus) in the river and creek valleys. Buxus is the main shrub component (up to 20\%) in the Taravilla palynological sequence. Pollen indicators of human activity are frequent and varied (Cichorioideae, Asteroideae, Artemisia, Centaurea, Rumex, Plantago, Chenopodiacee, Brassicacee...). The presence of Cerealia type in this mountain lake reflects the importance of winter cereal farming in the region. Olea and Juglans also are indicative of regional crops. The presence of Asphodelus could suggest frequent forest fires, either wild of human induced. In general, the pollen assemblages are similar to those from the nearby Laguna de la Cruz (Cuenca), previously studied by Burjachs (1996).

Aquatic plants, as Potamogeton, are present in the whole record indicating that the lake was relatively deep during the recorded period. Fluctuations in the percentages of Cyperaceae and hydrohygrophytes (from 20 to $50 \%$ ) would reflect changes in the surface area of the palustrine-wetland complex in the northeastern margin of the lake. Peaks in hydrohygrophytes would correspond to periods with more development of the wetland.

The decrease in Pine and the increase in deciduous and thermophilous trees in the upper $80 \mathrm{~cm}$ could be an indicator of anthropogenic pressure in the watershed during the last centuries or a result of humidity increase. An increase in rainfall cannot be completely rule out, since some pollen records from the area also show a recovery of thermophilous taxa (Burjachs, 1996), and the increase in flood events registered in our core could also be related to increase in precipitation after some of the coldest periods of the Little Ice Age (Benito et al., 2003a). A similar decrease in Pinus and an increase in Quercus, Betula and Buxus occur in the 
nearby Laguna de la Cruz (Burjachs, 1996) and it is chronologically well-constrained because of the varved nature of the record as the beginning of the $18^{\text {th }}$ century (ca. $1703 \mathrm{AD}$ based on varve counting). This change has been related to the decrease of the grazing pressure cause by the decline of the Mesta, the powerful Castilian Medieval Association of shepherds. The need for more pastures during medieval times led to the deforestation of large areas with the corresponding increase in Pine.

\section{Ostracods}

The ostracode assemblage from Taravilla $1 \mathrm{~A}$ is dominated by individuals of Candona sp and llyocypris $\mathrm{sp}$. This assemblage is typical of an environment with flowing water affected by stream input. The dominance of Candona sp. could indicate relatively deep waters with some restricted circulation. The number of ostracode valves in the sediment samples is very low, and some samples $(50,70$ and $100 \mathrm{~cm})$ lacked any ostracods. Some samples devoid of ostracodes correspond to coarse sandier facies, with low preservation potential. Others correspond to dark grey, faintly laminated mud facies. The presence of authigenic calcite in these intervals suggests that the absence of ostracodes is not due to carbonate dissolution processes. Most likely, restricted water circulation at the bottom and low oxygen contents in the deep areas of the lake, impeded survival of benthic ostracodes. The sample from $80 \mathrm{~cm}$ depth contains only llyocypris sp., suggesting more stream input into the lake.

\section{Stable Isotope Geochemistry}

Stable isotope data from modern tufa provide information on water temperature, water isotopic composition, paleohydrology (evaporation effects, residence time) and the carbon cycle (Andrews et al.,1993, 1997; Horvatincic et al., 2003). Older tufa deposits have also proved to contain archives of past environmental conditions (Pazdur et al., 1988; Durán, 1996; Andrews et al., 2000). In order to test the potential of the Taravilla tufa and lake sediments as environmental and climate records, lacustrine sediments, tufas, and sediments and rocks from the watershed were sampled. The selected core samples came from core A and B (center of the lake) and D (palustrine areas); the tufa samples were collected in the barrage, the springline tufa and small stromatolitic formations from the inlet; sediments were collected in the inlet creek; Cretaceous carbonate rocks from the watershed were also sampled. Ostracods from core A1 were also analyzed. All data are plotted in a $\delta^{18} \mathrm{O}-\delta^{13} \mathrm{C}$ graph in Figure 8A.

Tufa and ostracod samples are monomineralic, authigenic material while carbonate lake muds are admixtures of different carbonate sources. Consequently, the environmental information stored in the isotope data from tufa and ostracods is likely easier to decode. Tufa samples show the most negative $\delta^{13} \mathrm{C}(-8$ to - 
$10.5 \%$ ) and $\delta^{18} \mathrm{O}$ values (-6 to $-8 \%$ ) of the whole data set. The most negative $\delta^{13} \mathrm{C}$ values correspond to stromatolite tufa facies from the springline tufa and the recent stromatolite fabrics developed in small channels close to the inlet. The Taravilla tufa stable isotope compositions are very similar to those reported from other Spanish sites: Alcaraz tufa (Andrews et al., 2000), Eastern Iberian Range (Sancho et al., 1997; Peña et al., 2000), and they plot in the same field of the other lowland European stream tufas defined by Andrews et al $(1993,1997)$. These values are coherent with the range of isotopic compositions measured in the Taravilla spring and lake water (Fig. 3A and B). As it has been noted in other cases (Deines et al., 1974; Andrews et al., 1997, 2000), the $\delta^{13} \mathrm{C}$ (DIC) increases along water flows: values from the inlet and the springs are more negative than those from the Taravilla lake and the outlet; values from the Tajo river are the most positive (Fig. $3 \mathrm{C}$ ). The $\delta^{18} \mathrm{O}$ range (-6 to $-8 \%$ ) is coherent with the oxygen isotopic composition measured in the lake and springs (Fig. $3 \mathrm{~A}$ and $\mathrm{B}$ ).

Ostracod values from core $\mathrm{A} 2$ show similar $\delta^{13} \mathrm{C}$ range, although with some even more negative values, and generally higher $\delta^{18} \mathrm{O}$ values than tufa samples. The range in both isotopes shows enriched composition compared to the measured $\delta^{13} \mathrm{C}$ DIC (-11 to $\left.-13 \%\right)$ and the $\delta^{18} \mathrm{O}(-7.7$ to $-8.7 \%)$ in lake waters values (Fig. 3). Lake effects associated with preferential degassing, exchange with the atmosphere and evaporative effects can explain this enrichment. Down core fluctuations in core A2 (Fig. 5) show little variations and no preferential trend, suggesting no large hydrological or limnological changes during the last centuries.

The carbon and oxygen isotope compositions of the lake sediment samples plot in a group between the tufa and the watershed carbonate values (Fig. 8A). Both, the $\delta^{18} \mathrm{O}$ and the $\delta^{13} \mathrm{C}$ range are large (-2 to -10 $\%$ and -3.5 to $-9 \%$, respectively). Samples group by core location. Samples from core A1 and A2 show the largest range, and the most distinctive lineal distribution. The values from both cores are similar, as expected, since both cores were retrieved in the same area and show similar stratigraphy. Samples from core B plot to the most positive end of the range, and samples from core D plot generally towards the more negative end of the distribution range.

The isotope records from cores $\mathrm{A} 1$ and $\mathrm{A} 2$ show parallel $\delta^{18} \mathrm{O}$ and the $\delta^{13} \mathrm{C}$ curves and similar trends: low and relatively decreasing values at the base, relatively higher in the middle and decreasing at the top (Fig. 5). The more detailed sampling interval in core A1 allows comparison with other proxies. The similarities between the isotope curves and the dolomite content curve is striking, and demonstrate that the isotope values of the bulk carbonate samples are controlled by the mixing of different carbonate minerals. Three 
different sources contribute to the bulk carbonate in the Taravilla lake sediments: one with heavier isotope compositions (dolomite from Cretaceous formations), and two with more negative isotope values (calcite from the springline tufa structure, and calcite generated in the lake as charophytes, bio-induced crystals). Isotope compositions of samples with lower clastic content (lower dolomite content) as those at the bottom and top of core A2, show similar compositions than authigenic carbonate (ostracods) from the same levels (Fig. 5 and $8 A)$. Core $B$ shows generally heavier values than $A 1$ and $A 2$, but a similar trend of higher values related to more clastic facies, and decreasing values at the top. Core $D$ values are generally more negative, also correlating with a lower dolomite content of the cores (Fig. 5 and 8A).

The $\delta^{13} \mathrm{C}$ values of organic matter show a large range (-19 to $\left.-31 \%\right)$, with the more positive values in the sediments from the creeks in the watershed and the Cretaceous rocks and the more negative in tufas and some lacustrine sediment samples (Fig. 8A). A cross plot $\delta^{13} \mathrm{C}$ (carbonate) - $\delta^{13} \mathrm{C}$ (o.m.) shows three main groups (Fig. 8B): travertine and tufa with the most negative values, the lacustrine sediments with ${ }^{13} \mathrm{C}$ (o.m.) lower than $-25 \%$ and $\delta^{13} \mathrm{C}$ (carbonate) between -4 and $-8 \%$, and the sediments and rocks from the watershed with higher values. This distribution may reflect the different main organisms associated to the tufa (mosses, littoral) and lake (aquatic) subenvironments. Modern terrestrial and littoral (Phragmites, reeds) plants have more negative $\delta^{13} \mathrm{C}$ (o.m.) values (-28.9\%) than aquatic (-24 to - $25 \%$ ), and lacustrine algal material ( $-20 \%)$

\section{DISCUSSION}

\section{Chronology of the tufa formation}

Available dates suggest two main phases of tufa formation in the Taravilla system: Late Pleistocene (around $140 \mathrm{kyrs}$ ) and Lateglacial to Early Holocene. The most important episodes of tufa formation in Spain are associated to warmer and wetter conditions than current climate (Vaudour, 1994; Pedley et al, 2003, Sancho et al., 1997; Martín-Algarra et al., 2003; Ordoñez et al., 2005). In most cases described in Spain, those phases correspond to the warmer and more humid interglacial stages. Tufas have developed in the Tajo River and its tributaries since the early Pleistocene to late Holocene and there are several currently active systems. In the Cifuentes River, a tributary of the Tajo River, paludal tufas have been dated as 91900 yrs BP (Gárgoles de Abajo deposits) and >350000 yrs BP (Ruguilla deposits) with U/Th series (Ordoñez et al., 1990). In another location in the Tajo River headwaters, periods of tufa development are also associated to interglacial periods (Ordóñez et al., 1990). Only a few kms from Taravilla, in the Peralejos de las Truchas 
area, Guerrero Domínguez and González-Martín (2000) described two tufa structures occurring in the Tajo River valley. Although there is no absolute dating, the tufa buildups located $25-30 \mathrm{~m}$ above the modern river valley are covered by periglacial slope deposits, ascribed to the Last Glacial Maximum, and are, consequently older (González et al., 1999). These Pleistocene tufa buildups along the Tajo River correspond to the large tufa buildup in the south-eastern slope of the Taravilla Lake. The bottom of the Tajo river valley is occupied by a series of younger tufa structures, more than $20 \mathrm{~m}$ thick and $500 \mathrm{~m}$ long that are described as phytoherms framestone prograding wedges. These structures are Holocene in age and likely correlate with the development of the barrage than close the Taravilla lake.

Other sites in the central areas of the Iberian Range show similar chronologies for main tufa construction phases. In the Ruidera National Park (Guadiana watershed, south of Taravilla) two periods of tufa formation are distinguished (Ordoñez et al., 2005): a) Late Pleistocene, with three phases (250-190, 13090, and 40-30 Kyrs BP) that seem to correlate with the interglacial periods OIS 7, 5 and 3, and b) Late Glacial (at around 16,500 yr BP), continued during the Holocene (6.8 - 7.3 ka BP and 4.6 kyrs BP) and slowed down today, but it is still active. At the southern end of the Iberian Range, in the Sierra de Alcaraz, tufa growth mostly occurred during the Pleistocene and the mid to late Holocene (6000-2700 yr BP) (Taylor et al., 1988; Gonzalez Martín et al., 2000). Detrital deposition during the period $2700-500$ yrs BP is related to anthropogenic brushwood clearance. During the last 500 yrs fluvial erosion and trenching reflects a new dynamics induced by increase extensive agricultural and forestry practices and water power mill uses (Gonzalez Martín et al., 2000).

The occurrence of two main phases of tufa construction has been described in other sites in the Iberian Range. In the Mijares River (Eastern Iberian Range) the oldest fluvial tufa structure is upper Pleistocene in age (from 200,000 to 50,000 yrs BP) and reaches up to $120 \mathrm{~m}$ in thickness, and the younger one is Holocene in age (10,000-5000 yrs BP) and $35 \mathrm{~m}$ in thickness (Peña et al., 2000). In the Guadalaviar River, not far from the Tajo River headwaters, the highest growth of tufa occurred during the early Holocene (6800-7300 yr BP) and transition to the late Holocene (4600 yr BP) (Sancho et al., 1997). Further East in the Iberian Range (Puertos de Beceite, Matarraña River), three episodes of tufa growth have been documented (Martínez-Tudela et al, 1986): 7200-8000, 4000-4900 and 2600-3000 yrs BP). In the northern end of the Iberian Range, tufa also started to accumulate in the early Holocene (Llanos et al., 1998).

Tufa maximum development in the Mediterranean region has been related with the last interglacial (Henning et al., 1983). Tufa deposition in Mediterranean rivers seem to be restricted to warm periods, while 
cold - and arid - Pleistocene and Holocene phases seem to correlate with periods of decreased or null activity (Soligo et al., 2002; Ordoñez et al., 2005). Three periods or maximum travertine and speleothem deposition in Spain have been identified: oxygen isotope stages 9 and 7 (around $250000 \mathrm{yr}$ BP), last interglacial (oxygen isotope stage 5) and Lateglacial/Holocene (Durán, 1996, Torres et al, 1996). The Taravilla tufa system records the two last phases of increased tufa activity. Dry periods usually result in weakening and karstification of the barrage and deposition of detrital tufas. In an European context, rates of tufa formation were high in early and mid- Holocene and declined markedly thereafter (Pazdur et al., 1988; Goudie et al., 1993). Deforestation through the induced changes in hydrological river regimes, soil and biological activity has been considered the most likely mechanism to explain the widespread nature of tufa decline in Europe.

\section{Environmental, climate and palaeohydrological record.}

The short cores of the Taravilla lacustrine record only cover the last $500 \mathrm{yrs}$, and the longest cores retrieved in 2004 span the record up to 1700 yrs ago (Fig. 7). The sedimentological, compositional and magnetic data provide a detailed reconstruction of the depositional evolution of the lake for the last $1700 \mathrm{yrs}$. The isotope, pollen and ostracod data from the short cores allow a more detailed reconstruction of the last 500 yrs.

Facies analyses show that clastic depositional processes are dominant in the Taravilla karstic Lake. The Taravilla Lake is sensitive to precipitation as the outlet becomes non-functional during dry periods and overflows during wet seasons, and inlet is only functional during intense floods. On the other hand, the lake, located at the Tajo River headwaters, should archive some information on the palaeohydrological changes in the watershed. The fining upward sequences in the Taravilla sedimentary record are indicators of periods of increased alluvial activity of the inlet, and consequently, of more intense floods in the basin. Carbonate content in the sediments, and facies are proxies for paleofloods, because most of the carbonate occurring in the sediments is transported into the basin during floods. Magnetic susceptibility values are smaller in these flood-related, coarse, carbonate-rich sediments (Fig. 6 and 7) and so it correlates with clastic facies. Four main periods of depositional dynamics are distinguished in the record:

a) during deposition of Unit 4, at least ten main sequences composed of alternating darker and lighter carbonate silt occur. Absence of sandy layers suggests that sediment delivery to the lake was restricted, either by a more vegetated watershed or because of the lower intensity of the flood 
discharge. Although there is no change in the cyclicity in the upper part of unit 4 , there is an increase in carbonate content, that could indicate higher sediment availability in the watershed.

b) Flood events marked by coarse, carbonate-rich facies were less frequent, and deposition was dominated by darker, organic-rich carbonate mud and silt during deposition of unit 3. During this period, organic productivity in the lake increased (Fig. 6). Flood intensity and frequency were smaller.

c) The largest flood recorded in the Taravilla Lake delivered almost $1 \mathrm{~m}$ of sediments to the center of the lake (base of unit 2). Relatively organic-rich mud deposited on top without any indication of more floods in the upper part of unit 2. This large flood is likely related to the gravel-sand-silt unit from core D (Fig. 7).

d) Unit 1 shows again an increase number of flood, although none of the intensity of the previous one.

The palaeoflood hydrology of the Tajo River has been reconstructed in detail from slackwater deposits and paleostage indicators in the central part of the catchment (Benito et al.,1996, 2003a,b). The record shows clusters of floods during the early Holocene $(9.5-6.7 \mathrm{kyrs})$, almost no floods during the Mid Holocene, a reactivation after $1200{ }^{14} \mathrm{C}$ yr BP., and an increase during the last 500 years. The strongest floods during the last 2000 yrs occurred in the following periods: 1200 to $950{ }^{14} \mathrm{C}$ yr BP (AD 785-1205), ca. $410{ }^{14} \mathrm{C}$ yr BP (AD 1450-1500), and 170 to $80{ }^{14} \mathrm{C}$ yr BP (AD 1670-1950). The record may be biased due to the post-flood erosion of some of the mid Holocene deposits and the increase in the available information on most recent flood events (Benito et al., 2003a, b). Because of the large size of the watershed, years with occurrence of extreme floods are related to anomalous wetter conditions, and westerly-dominated circulation, with the Azores high at lower latitudes and a low index zonal circulation over the Atlantic. A connection of the flood frequency with secular solar activity variation and low NAO index has been proposed by Vaquero (2004). Periods with increased flood magnitude and/or frequency are related to increased winter precipitation. During the late Holocene, the flood record is sparse, likely to post-flood erosion of the sediments, although there are indications of large floods during the last $3000 \mathrm{yrs}$. Extensive deforestation in central Spain occurred after 2500 yr BP (Gil García et al., 1993; García-Antón et al., 1997; Ruiz-Zapata, 1999; Franco et al., 2005) and may have affected peak discharges.

The chronological record of the Taravilla cores does not allow a detail analysis of flood frequency during the last 1700 yrs. Besides, the flood history in the headwaters where Taravilla is located could be 
different than in the middle reaches of the river, because of the different fluvial dynamics and timing of the maximum rainfalls (early spring in Taravilla). However, some similarities can be drawn. The increase in floods during the last 500 yrs (AD 1650 to 1950) in the Tajo River (Benito et al., 2003a) corresponds to the increase flood frequency in the upper Units 2 and 1 in the Taravilla record, that also represent deposition during the last 500 years. The low flood frequency and magnitude period between $950-410{ }^{14} \mathrm{C}$ yr (AD 1205-1450) is coherent with deposition of Unit 3. One of the largest floods, also documented by historical sources, occurred between AD 1150 and 1200 (Benito et al., 1996; 2003b). Because of the stratigraphical location of Unit 2, it is unlikely that the main flood recorded in Taravilla corresponds to the main flood in the central reaches of the Tajo River. It is more likely that the increased in frequency and floods between 1200 and $950{ }^{14} \mathrm{C}$ yr BP could correspond to the upper part of Unit 4. The base of the core corresponds to another period of reduced flood intensity between 1200 and $1700{ }^{14} \mathrm{C}$ yr BP.

The increase in flood frequency during the last 500 years coincides with other evidences of wetter and colder climate and environmental change in Central Spain and in Europe during the Little Ice Age $\left(15^{\text {th }}\right.$ to $19^{\text {th }}$ century: Porter 1986; Grove, 1988, Pfister et al., 1998; Pfister and Brazdil, 1999, Starkel, 1991). Documentary records suggest that increased flood frequency periods correspond to the initial and final states of the main climatic fluctuations (MWP, LIA), periods of adjustment for the hydrological system (Benito et al., 2003). Changes in the land-uses - some deforestation for grazing (Stevenson et al., 1991; Davis, 1994; Burjachs, 1996; Juliá et al., 1998; Stevenson, 2000; González-Sampériz and Sopena, 2002) - could have helped to increase flood intensity and frequency during the last centuries. An increase in lake level and the development of meromixis occurred in the nearby La Cruz Lake (Julia et al., 1998) and it has been interpreted as a result of the combined effects of woodland clearance, agricultural expansion to the detriment of nomadic livestock and transhumance (Mesta) and colder climatic phases. The sediment sequence from the large littoral zone to the northeast of the lake (core $\mathrm{D}$ ) also shows evidences of lake surface area increase after the $\mathrm{XV}^{\text {th }}$ century, that could be correlated with the end of the Medieval Warm Period. The growth of littoral vegetation at the mouth of the inlet could have prevented the coarser sandy sediments to reach the center of the lake during the last century.

\section{CONCLUSIONS}

The combined study of the tufa formations and the lake sediments from the Taravilla system provides useful paleoenvironmental and paleohydrological information, in spite of the chronological uncertainties and the complex interpretation of some of the proxies. Two main periods of tufa formation are present in Taravilla. 
The perched springline tufa located in the eastern margin of the hanged valley is the oldest, and although it could have been active earlier, the main phase seems to be around $140 \mathrm{ka}$, during the transition from glacial isotope stage 6 to the last interglaciar, isotope stage 5 . The barrage tufa that holds the Taravilla Lake developed later and it is associated to a Lateglacial to Early Holocene phase. These two phases of maximum tufa growth have been detected and dated in several other tufa systems in Spain and in the Mediterranean region.

The Taravilla Lake deposition has been mostly dominated by clastic processes during the last 2000 years. A detailed sedimentary facies analyses combined with physical properties (magnetic susceptibility), TOC, TIC, grain size and geochemical composition allowed the reconstruction of changes in sediment input from the watershed and the limnological history of the lake. Fining upward sequences and sands and coarse silts reflect periods of increased alluvial activity of the inlet and sediment delivery. Four sedimentary units are identified from base to top: i) unit 4 is characterized by low intensity floods, and an increasing trend towards the top; ii) unit 3 represents a period of decreased flood frequency and intensity; iii) unit 2 encompasses the largest flood in the last 2000 years of the Taravilla record that delivered more than $1 \mathrm{~m}$ of sediment to the center of the lake; iv) unit 1 shows an increase in flood frequency during the last centuries. Although the Taravilla chronology does not allow a detail analysis of flood frequency, the reconstructed evolution is coherent with the palaeoflood history of the Tajo River, particularly with an increase during the last 500 years. The increase in flood frequency coincides with other evidences of wetter and colder climate and environmental change in Central Spain and in Europe during the Little Ice Age. Pollen data show an increase in thermophilous taxa during the last centuries that is likely related to decreasing grazing pressure in the region after medieval times. The progradation of the palustrine area in the Taravilla basin and the progressive colonization by littoral vegetation is related to the large clastic input from the inlet.

Stable isotope compositions of tufa provide useful paleoenvironmental information. The values of the Holocene and Pleistocene Taravilla tufa are similar to those published from other Spanish sites and those of low land European streams and wooded Alpine streams as defined by Andrews et al (2001). The isotopic compositions are coherent with the range of isotopic compositions measured in the modern Taravilla spring and lake water. The dominance of clastic depositional processes and the input of detrital carbonate from the Creataceous formations hinder the use of lake mud stable isotopic compositions as environmental indicators.

\section{ACKNOWLEDGEMENTS}


Financial support for research at Laguna Taravilla was provided by the Spanish Inter-Ministry Commission of Science and Technology (CICYT), through the projects IBERARID (REN 2000-1136) "Arid periods in the Mediterranean areas of the Iberian Peninsula since the last glacial maximum: chronology, characterization and paleoclimate implications" and LIMNOCLIBER (REN2003-09130-C02-02) "Climate and hydrological variability in the Iberian Peninsula since the Last Glacial Maximum: high-resolution analyses of lacustrine cores and its implications for the climate change". We thank the Director and the staff of the "Parque Natural del Alto Tajo" for their help during fieldwork and also for access to unpublished data. Daniel Ariztegui and Michael Schnellmann (Geneve University, ETH, Switzerland) performed the seismic survey of the lake. Dirk Verschuren (Gent University, Belgium) helped to retrieve and sample the 2001-2002 cores. We are most grateful to Doug Schnurrenberger, Anders Noren and Mark Shapley (LRC, University of Minnesota, USA) for the 2004 coring expedition.

\section{REFERENCES}

Andrews, J.E., Pedley, M., Dennos, P.F., 2000. Palaeoenvironmental records in Holocene Spanish tufas: a stable isotope approach in search of reliable climatic archives. Sedimentology 47, 961-978.

Andrews, J.E., Riding, R.,and Dennis, P.F. 1993. Stable isotopic compositions of Recent freshwater cyanobaterial carbonates from the British Isles: local and regional environmental controls. Sedimentology 40: 303-314.

Andrews, J.E., Riding, R., and Dennis, P.F. 1997. The stable isotope record of environmental and climate signals in modern terrestrial microbial carbonates from Europe. Palaeogeogr., Palaeoclimatol., Palaeoecol., 129: 171-189.

Benito G., Díez-Herrero A. and Fernández de Villalta M. 2003. Magnitude and frequency of flooding in the Tagus Basin (Central Spain) over the last millennium. Climate Change 58: 171-192.

Benito, G., Sopeña, A., Sánchez-Moya, Y., Machado, M.J., Pérez-González, A., 2003. Palaeoflood record of the Tagus River (Central Spain) during the Late Pleistocene and Holocene. Quaternary Science Reviews 22, 1737-1756.

Benito, G.; Machado, M.J. \& Pérez-González, A. (1996). Climate change and flood sensitivity in Spain. In: Branson, J., Brown, A.G., Gregory, K.J. (Eds.). Global Continental Changes: the Context of Palaeohydrology, Geological Society of London Special Publication No. 115, 85-98. 
Boyle J. 2001. Inorganic geochemical methods in palaeolimnology. In: Last W.M. and Smol J.P. (eds), Tracking environmental change using lake sediments, vol. 2: Physical and geochemical methods. Kluwer Academic Publishers, Dordrecht, The Netherlands, pp. 83-141.

Boyle J. 2004. A comparison of two methods for estimating the organic matter content of sediments. J. Paleolimnol. 31: 125-127.

Burjachs, F. 1996. La secuencia palinológica de la Cruz (Cuenca, España). Estudios Palinológicos 31-36.

Buurman P., Pape Th. and Muggler C.C. 1997. Laser grain-size determination in soil genetic studies: I. Practical problems. Soil Sci. 162: 211-218.

Chen, J., Zhang, D.D., Wang, S., Xiao, T., Huang, R., 2004. Factors controlling tufa deposition in natural waters at waterfall sites. Sedimentary Geology 166, 353-366.

CSIC, 1976. Comisión de métodos analíticos. An. Edafol. Agrobiol. 35: 813-814.

Davis, B. A. S., 1994. Paleolimnology and Holocene environmental change from endorheic lakes in the Ebro Basin, north-east Spain, Ph. D. Thesis, University of Newcastle upon Tyne, 317 pp.

Deines, P., Langmuir, D., Harmon, R.S., 1974. Stable carbon isotope ratios and the existence of a gas phase in the evolution of carbonate groundwaters. Geochimica and Cosmochimica Acta 38, 1147-1164.

Durán, J.J. 1996. Los sistemas kársticos de laprovincia de Mealaga y su evolución: Contribución al conocimiento paleoclimático del Cuaternario en el Mediterreaneo occidental. PhD Thesis, Complutense University of Madrid, Spain.

Ford, T.D., Pedley, H.M., 1996. A review of tufa and travertine deposits of the World. Earth-Science Reviews 41, 117-175.

Forester R.M. 1988. Non marine calcareous microfossil sample preparation and data acquisition procedures. United States Geological Survey Technical Procedure HP-78 RI: 1-9.

Franco, F., García-Antón, M., Maldonado, J., Morla, C., Sainz-Ollero, H. (2005). Ancient pine forest on inland dunes in the Spanish northern Meseta. Quaternary Research 63, 1-14.

García-Antón, M., Franco, F., Maldonado, J., Morla, C., Sainz-Ollero, H. 1997. New data concerning the evolution of the vegetation in Lillo Pinewood (León, Spain). Journal of Biogeography 26, 929-934.

Gedda, B., Lemdahl, G., Gaillard, M.J., 1999. Late glacial and Early Holocene environments inferred from a tufa deposit at Fyledalen, Sweden. Geol. Fören. Stockh. Förh. 121, 33-41.

Gil García, M.J., Tomas, R., Ruiz-Zapata, B. (1993). Paleovégétation pendant le Quaternaire recent dans le Puerto de Morcuera "Col de Morcuera" (Système Central, Espagne). Quaternaire 4 (1), 31-37. 
González Amuchastegui, M.J. and González, J.A. 1993. Estudio geomorfológico de las acumulacioens travertínicas y tobáceas del Alto Valle del Tajo (Peñalen-Huertapelayo). II Reunión del Cuaternario en España y Portugal. ITGE-AEQUA 1: 99-109.

González Amuchastegui M.J. 1998. Geomorfología y etapas de karstificación en la Rama Castellana del Sistema Ibérico. Est. Geogr. LIX, 232, 423-441.

González Martín, J.A., García del Cura, M.A., Ordóñez, S., 1989. Formaciones tobáceas en los valles de Tajuña y Tajo, Excursión C-4. Reunión de Cuaternario Ibérico, Madrid 25-29 de Septiembre de 1989. Assoc. Española Estudio del Cuaternario (AEQUA) - Grupo Trabalho Portugies Estudo do Cuaternario (GTPEQ), 39 pp.

González Martín, J.A., Ordóñez, S., Fernández, A., García del Cura, M.A., 2000. Acumulaciones tobáceas holocenas en la Sierra de Alcaraz (Albacete, España). Geotemas 1 (3) pp. 369-373.

González, J.A., Asensio, I., Fernández, A., García, R., González Amuchastegui, M.J., Guerrero, L., Rubio, V, 1999. Acumulaciones de origen frío en el modelado de los paisajes de la Rama Castellana del Sistema Ibérico y de la Submeseta Sur. In: Actas IV Reunión Int. Permafrost Ass. Teruel.

González-Sampériz, P. and Sopena, M. C. 2002. Recent Holocene palaeoenvironmental evolution in the Central Ebro Basin (NE Spain). Quaternary International, 93-94, 177-190.

Goudie, A.S., Viles, H.A., Pentecost, A., 1993. The Late-Holocene tufa decline in Europe. Holocene 3, 181186.

Grove, J.M., 1988. The Little Ice Age. Methuen, London, 498 pp.

Guerrero Domínguez, L., and González Martín, J.A., 2000. Características geomorfológicas del modelo de construcción tobáceo del Alto Tajo en su fondo de valle (Peralejos de las Truchas-Guadalajara). Geotemas 1(3) pp. 375-378.

Gutiérrez, M., Peña Monné, JL., 1975. Karst y periglaciarismo en la Sierra de Javalambre (provincia de Teruel). Boletín Geológico y Minero 1975, 561-572.

Gutierrez-Elorza , M. \& Peña Monne, J.L. 1979. El karst de Villar del Cobo (Sierra de Albarracín). Estudios Geológicos IGME, 35: 651-654.

Heiri O., Lotter A.F. and Lemcke G., 2001. Loss on ignition as a method for estimating organic and carbonate content in sediments: Reproductibility and comparability of results. J. Paleolimnol. 25, 101-110.

Henning, G.J., Grün, R., Brunnacker, K., 1983. Speleothems, travertines and paleoclimates. Quaternary Research 20, 1-29. 
Horvatincic, N., Calic, R., Geyh, M.A., 2000. Interglacial growth of tufa in Croatia. Quaternary Research 53, 185-195.

IGME, 1989. Peralejos de las Truchas. Mapa Geológico de España, Escala 1: 50.000, hoja 539. 69 páginas, 1 mapa.

Julià, R., F. Burjachs, M.J. Dasí, F. Mezquita, M. R. Miracle, J.R. Roca, G. Seret \& E. Vicente, 1998. Meromixis origin and recent trophic evolution in the Spanish mountain lake La Cruz. Aquat. Sci. 60, 279-299.

Llanos, H., Quinif, Y., Abalos, B., 1998. Evolución geodinámica reciente de la Sierra de Cantabria (Álava) en base a la datación U/Th de carbonatos continentales de las cuencas de los ríos Inglares y Ebro. Bol. Geol. Min. 109-1, 3-12.

Martín-Algarra A., Martín-Martín M., Andreo B., Juliá, R. and González-Gómez, C. 2003. Sedimentary patterns in perched spring travertines near Granada (Spain) as indicators of the paleohydroogical and paleoclimatological evolution of a karst massif. Sedimentary Geology 161, 217-228.

Martínez Tudela, A., Cuenca, F., Santisteban, C. Grun, R. and Hentzsch, B. 1986. Los travertinos del Rio Matarraña Beceite (Teruel) como indicadores paleoclimáticos del Cuaternario. In: López-Vera (ed.) Quaternary Climate in Western Mediterranean,Madrid, 307-324.

Mezquita, F. \& M. R. Miracle 1997. Chydorid assemblages in the sedimentary sequence of Lake La Cruz (Spain) subject to water level changes. Hydrobiologia 360, 277-285.

Miracle, M.R., E. Vicente y C. Pedrós-Alió 1992. Biological studies of Spanish meromictic and stratified karstic lakes. Limnetica 8, 59-77.

Molina, J.A. 1996. Sobre la vegetación de los humedales de la Península Ibérica. (1. PhragmitiMagnocaricetea). Lazaroa 16: 27-88

Moore, P; Webb, J.A., Collinson, A., 1991. An illustrated guide to pollen analysis. London. Hodder and Stroughton. 216 pp.

Ordóñez, S., González Martín, J.A., 1979. Formaciones tobáceas del valle del Río Tajuña entre Brihuega y Masegoso (Provincia de Guadalajara). Estud. Geol. Inst. Invest. Geol. Lucas Mallada, 35, 205-212.

Ordóñez, S., González Martín, J.A., Fernández, A., García del Cura, M.A., 1986. Sedimentación carbonática actual y paraactual en las Lagunas de Ruidera. Revista de Materiales y Procesos Geológicos 4, 229255. 
Ordóñez, S., González Martín, J.A., Fernández, A., García del Cura, M.A., 1990. Datación radiogénica $\left(\mathrm{U}^{234} / \mathrm{U}^{238}\right.$ y $\left.\mathrm{Th}^{230} / \mathrm{U}^{234}\right)$ de los sistemas travertínicos del Alto Tajo (Guadalajara). Geogaceta 8, 53-56.

Ordoñez, S., González-Martín J.A., García del Cura, M.A. and Pedley H.M., 2005. Temperate and semi-arid tufas in the Pleistocene toRecent fluvial barrage system in the Mediterranean ara: The Ruidera Lakes Natural Park (central Spain). Geomorphology 69, 332-350.

Pazdur, A., Pazdur, M.F., Starkel, L. and Szulc, J. 1988. Stable isotopes of Holocene calcareous tufa in southern Poland as palaeoclimatic indicators. Quaternary Research 30, 177-189.

Pedley, H.M., Andrews, J.E., Ordóñez, S., González Martín, J.A., García del Cura, M.A., Taylor, D.M., 1996. Climatically controlled fabrics in freshwater carbonates: a comparative study of barrage tufas from Spain and Britain. Palaeogeography, Palaeoclimatology, Palaeoecology 121, 239-257.

Pedley, H.M., González Martín, J.A., Ordóñez, S., García del Cura, M.A., 2003. Sedimentology of Quaternary perched spring line and paludal tufas: criteria for recognition, with examples from Guadalajara Province, Spain. Sedimentology 50, 23-44.

Pedley, M. 1990. Classification and environmental models of cool freshwater tufas. Sedimentary Geology 68, 143-154.

Pedley, M., 1993. Sedimentology of the Late Quaternary barrage tufas in the Wye and Tahnkill valleys, north Derbyshire. Proceedings of the Yorkshire Geological Society 49, 197-206.

Peinado-Lorca , M. \& Martínez-Parras, J.M., 1987. La vegetación de España. Universidad de Alcalá de Henares: 165-196.

Peña, J.L., Sancho, C., Lozano, M.V., 2000. Climatic and tectonic significance of late Pleistocene and Holocene tufa deposits in the Mijares River Canyon, Eastern Iberian Range, Northeast Spain. Earth Surface Processes and Landforms 25, 1403-1418.

Pfister C., Schwarz-Zanetti G., Wegmann M. and Luterbacher J. 1998. Winter air temperature variations in western Europe during the Early and High Middle Ages (AD 750-1300). The Holocene 8: 535-552.

Pfister, C., Brázdil, R., 1999. Climatic variability in Sixteenth-Century Europe and its Social Dimension: A Synthesis. Climate Change 43, 5-53.

Porter, S.C., 1986. Pattern and forcing of Northern Hemisphere glacier variations during the Last Millennium. Quaternary Research 28, 27-48.

Rodrigo, M.A., Vicente, E. and Miracle, M.R., 1993. Short-term calcite precipitation in the karstic meromictic lake La Cruz (Cuenca, Spain). Verh. Internat. Verein. Limnol., 25: 711-719. 
Ruiz Zapata, B., Dorado Valiño, M., Gil García, M.J., Valdeolmillos Rodríguez, A., 1999. Efectos del Cambio Climático en la Región Mediterránea durante los últimos 3000 años. Universidad de Alcalá. Madrid.

Sancho, C., Peña, J.L., Meléndez, A., 1997. Controls on Holocene and present-day travertine formation in the Guadalaviar River (Iberian Chain, NE Spain). Zeitschrift für Geomorphologie 41, 289-307.

Santisteban J.I., Mediavilla R., López-Pamo E., Dabrio C.J., Ruiz Zapata M.B., Gil García M.J., Castaño S. and Martínez-Alfaro P.E. 2004. Loss on ignition: a qualitative or quantitative method for organic matter and carbonate mineral content in sediments. J. Paleolimnol. 32: 287-299.

Schnurrenberger D., Russel J. and Kelts K. 2003. Classification of lacustrine sediments based on sedimentary components. J. Paleolimnol. 29: 141-154

Soligo, M., Tuccimei, P., Barberi, R., Delitala, M.C., Miccadei, E., Taddeuci, A., 2002. U/Th dating of freshwater travertine from Middle Velino Valley (Central Italy): paleoclimatic and geological implications. Palaeogeography, Palaeoclimatology, Palaeoecology 184, 147-161.

Starkel, L., 1991. Fluvial environments as a source of information on climatic changes and human impact in Europe. In: Frenzel, B., Pons, A., Glaser, B. (Eds.), Evaluation of Climate Proxy Data in Relation to the European Holocene. G. Fischer Verlag, Stuttgart,

Stevenson, A. 2000. The Holocene forest history of the Montes Universales, Teruel, Spain. Holocene 10, 603610.

Stevenson, A.; Macklin, M.; Benavente, J.; Navarro, C.; Passmore, D. and Davis, B. A. S., 1991. Cambios ambientales durante el Holoceno en el Valle del Ebro: sus implicaciones arqueológicas. Cuaternario y Geomorfología $5,149-164$.

Stockmarr, J. 1971. Tablets with spores used in absolute pollen analysis. Pollen et Spores 13, 614-621.

Taylor, D.M.T., Pedley, H.M., Davies, P., Wright, M.W., 1998. Pollen and mollusc records for environmental change in central Spain during the Mid- and Late Holocene. Holocene 8, 605-612.

Torres, T. and 20 authors more, 1996. Aportaciones al conocimiento de la evolucion paleoclimática y paleoambiental en la peninsula Ibérica durante los dos últimos millones de años a partir del estudio de travertinos y espeleotemas. Empresa Nacional de Recursos Radioactivos, S.A. Technical Publications 3/96, $118 \mathrm{p}$.

Vadour, J., 1994. Évolution Holocène des vallée dans le Midi Méditeranee Français. Géographie Physique Quaternarie 48, 315-326. 
Vaquero, J.M., 2004. Solar signal in the number of floods recorded for the Tagus River Basin over the Last Millennium. Comment on "Magnitude and frequency in the Tagus Basin (Central Spain) over the last millennium" by G. Benito et al. 2003. Climatic Change 66, 23-26. 


\section{FIGURE CAPTIONS}

Figure 1. Geographic and Geological setting of Laguna Taravilla. A. Annual Rainfall distribution in Spain (Capel Molina 1981) and location of Laguna Taravilla $\left({ }^{*}\right)$. B. The Laguna Taravilla watershed. Isoaltitude lines every $100 \mathrm{~m}$, from $1450 \mathrm{~m}$ a.s.I to $1150 \mathrm{~m}$ a.s.I. C. Geological map.

Figure 2. A. General sketch of the location of the springline perched tufa, the barrage tufa and the Taravilla lake. B.Photograph of the Laguna de Taravilla and the tufa deposits.

Figure 3. Isotope survey of lake waters. A. D- ${ }^{18} \mathrm{O}$ cross plot of rain and meteoric waters. Most rain samples show the most negative compositions, although one sample show values similar to surface meteoric waters.B. Detail of the D- ${ }^{18} \mathrm{O}$ cross plot showing the values of the Taravilla tufa-lake system. C. $-\delta^{13} \mathrm{C}-$ $\delta^{18} \mathrm{O}$ cross plot of water samples from the Taravilla tufa-lake system.

Figure 4. Bathymetric map and seismic profiles from the Taravilla Lake.

Figure 5. Sedimentary facies and units, magnetic susceptibility, sediment composition indicators, selected geochemical profiles (values in ppm), stable isotope compositions, pollen and ${ }^{14} \mathrm{C}$ AMS dates from cores $A, B$ and $C$.

Figure 6. Sedimentary Facies and Units, TIC, TOC, magnetic susceptibility and ${ }^{14} \mathrm{C}$ AMS dates from core TAR04-1A-1K.

Figure 7. Stratigraphic correlation among all the cores. Correlation is based on sedimentary facies and magnetic susceptibility for the longer cores.

Figure 8. A. Cross plot of oxygen and Carbon stable isotope values from all samples. The fields and the Alcaraz isotope values are from Andrews et al (2000): 1. Alpine streams in unwooded areas and Alpine lakes; 2. UK lakes; 3. Low land European streams and wooded Alpine streams. B. Cross plot of carbon isotope values of bulk carbonates and organic matter. 


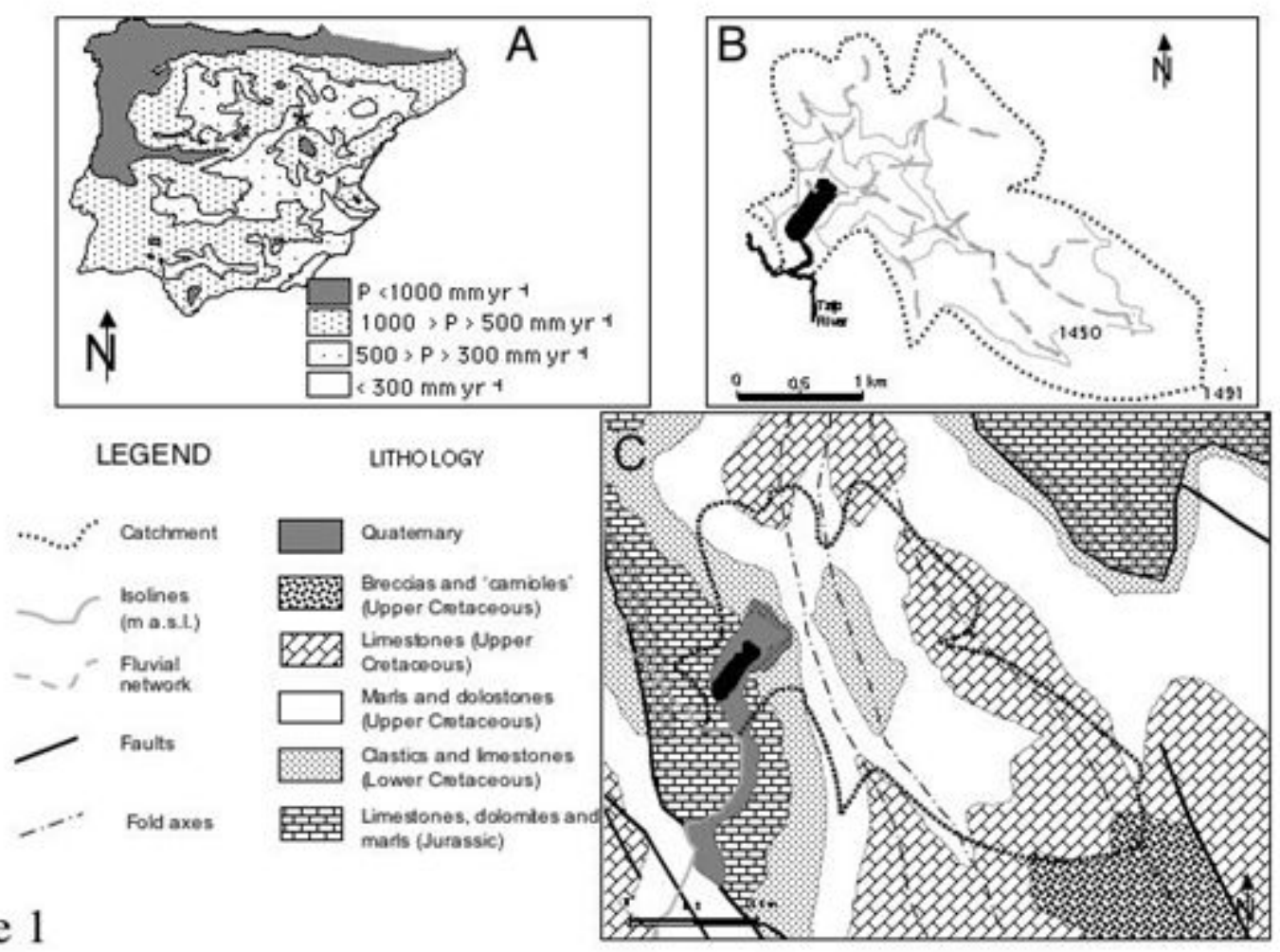

Figure 1 

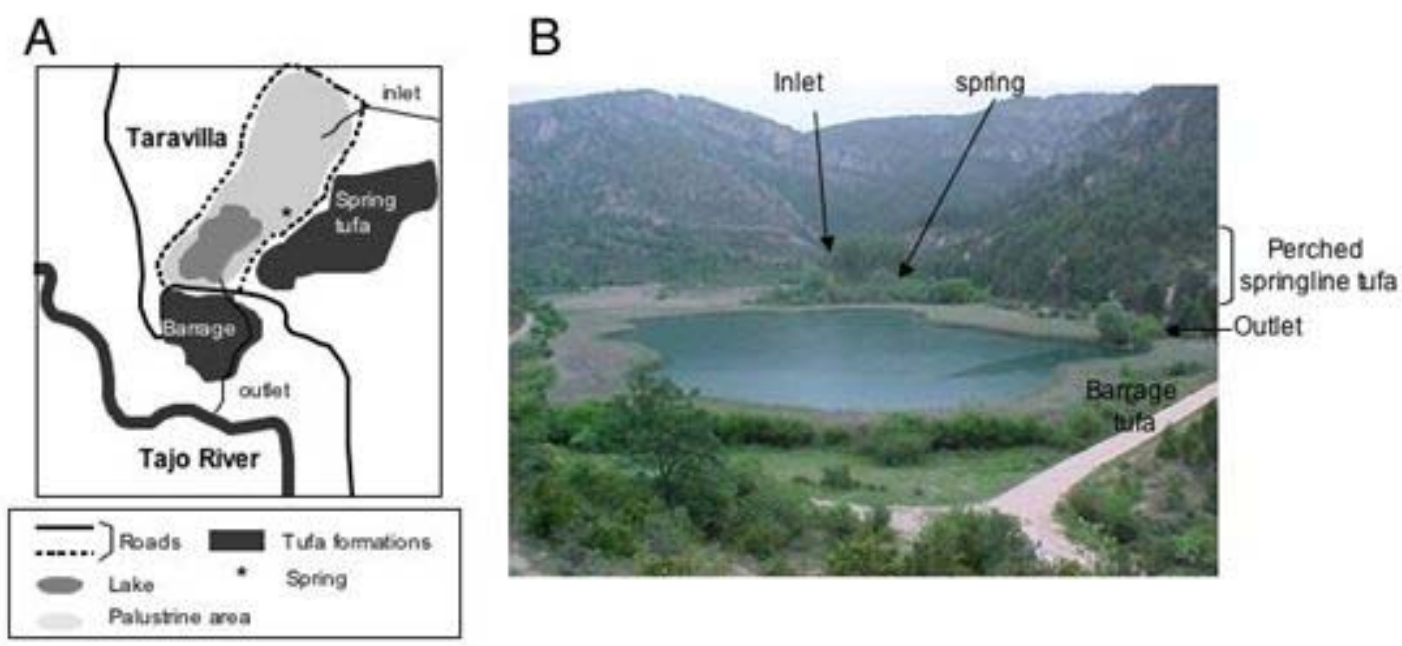

Figure 2 

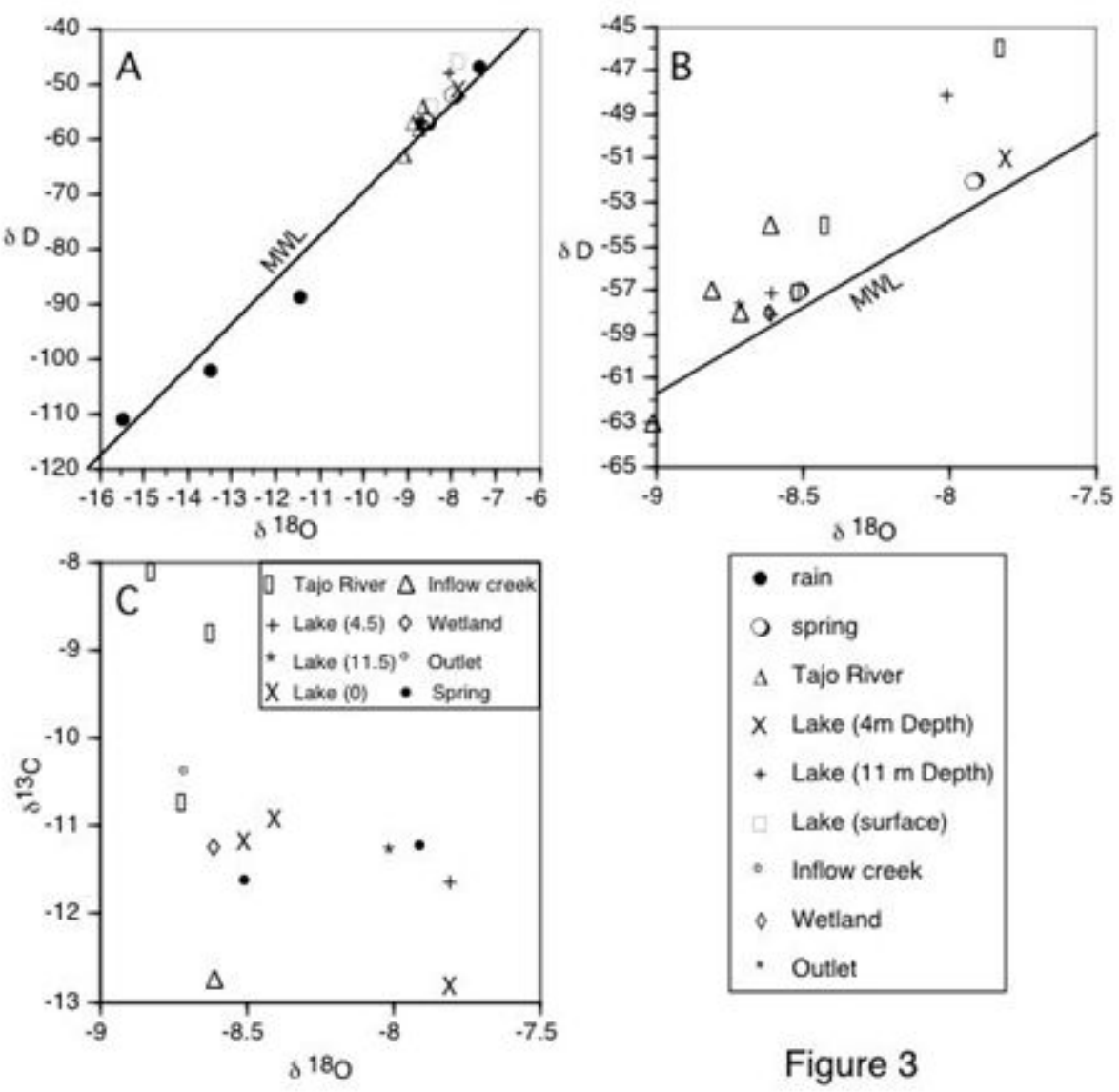

spring

$\Delta$ Tajo River

$X$ Lake (4m Depth)

+ Lake (11 m Depth)

Lake (surface)

Inflow creek

- Wetland

- Outlet

Figure 3 


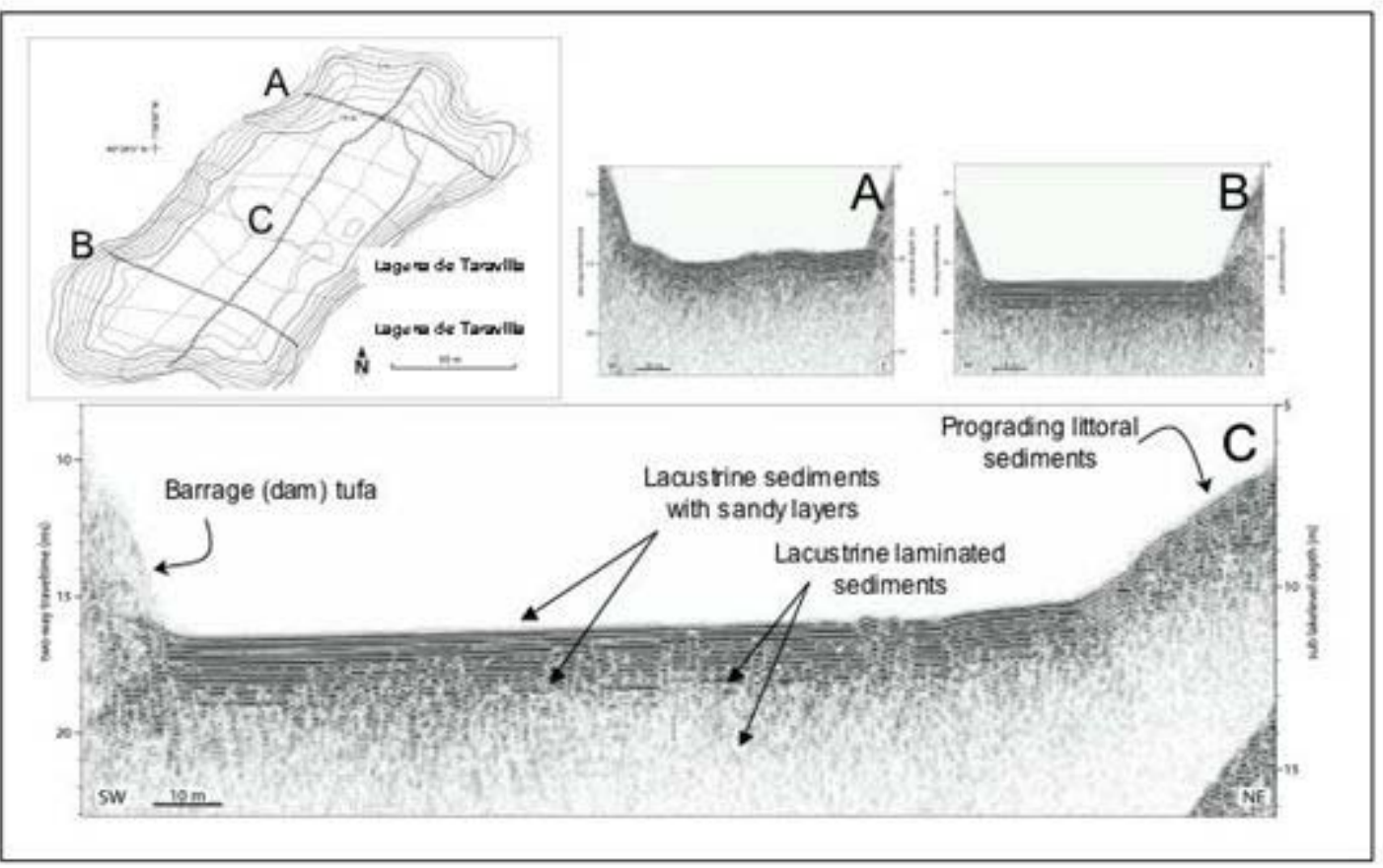

Figure 4 

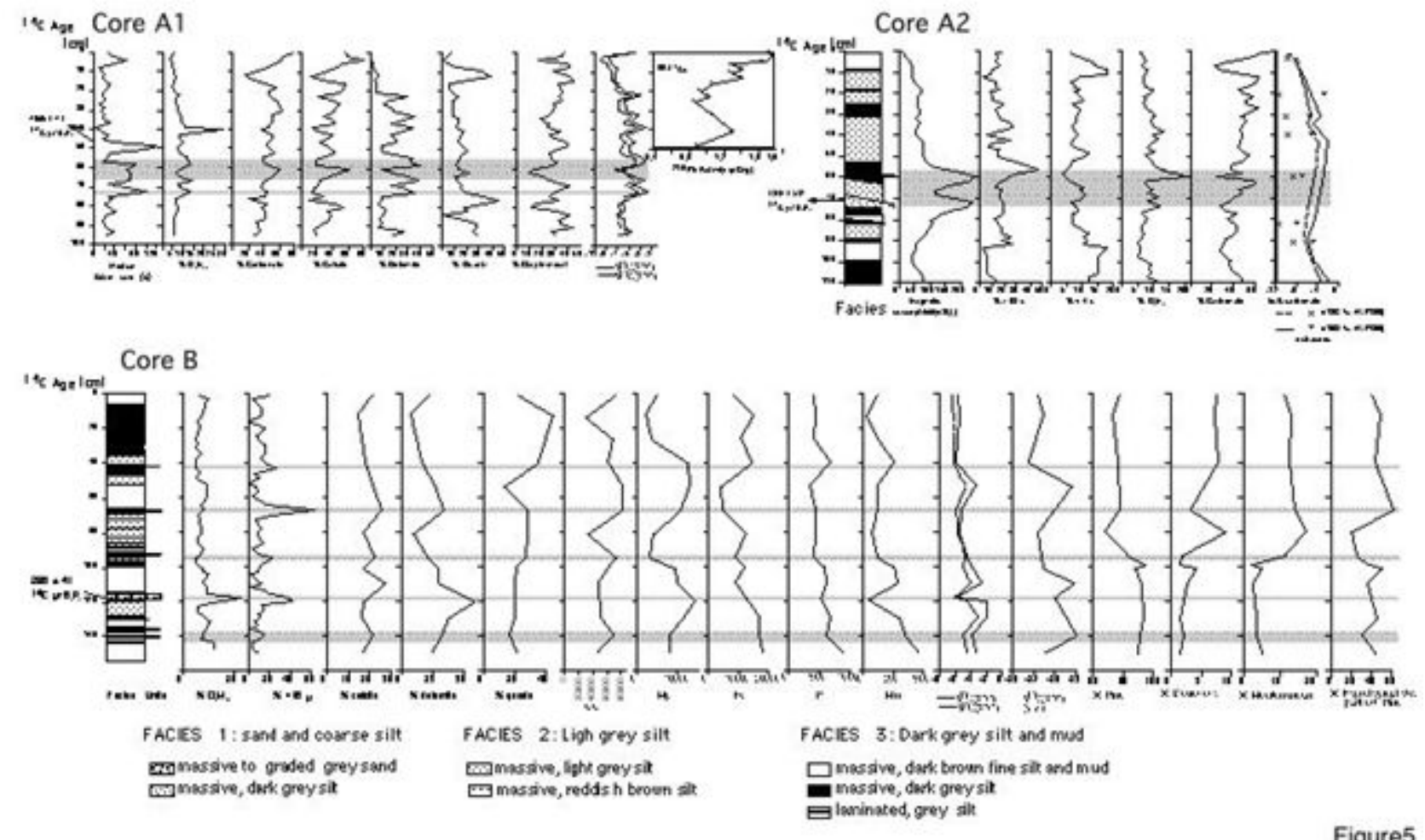

Figure5 


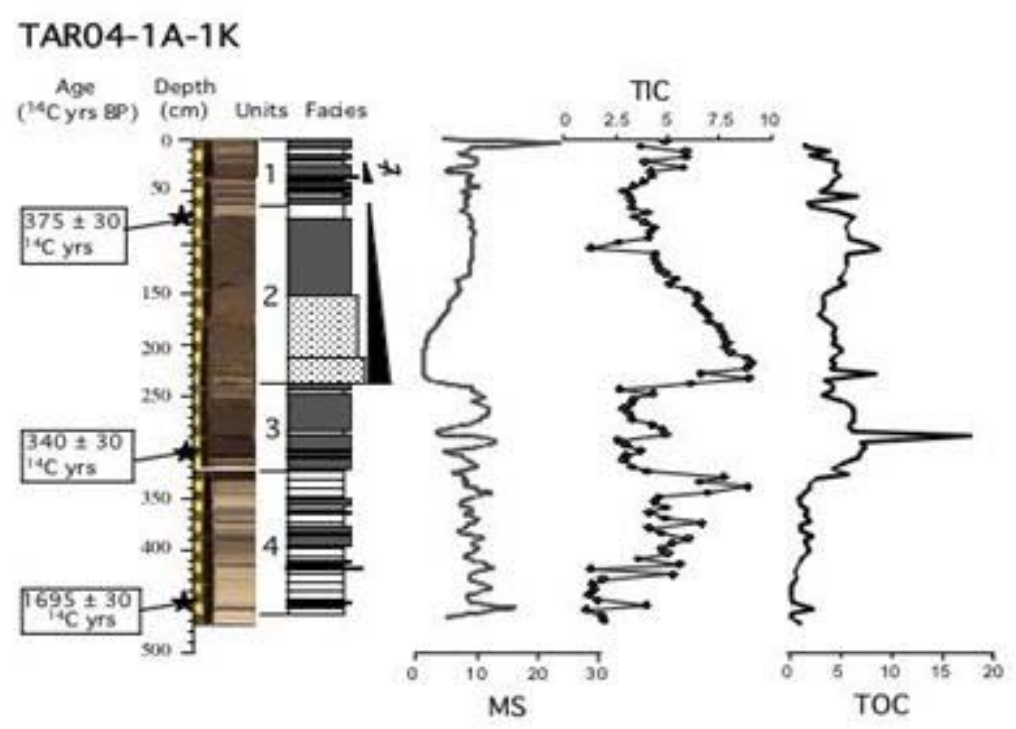

Figure 6 


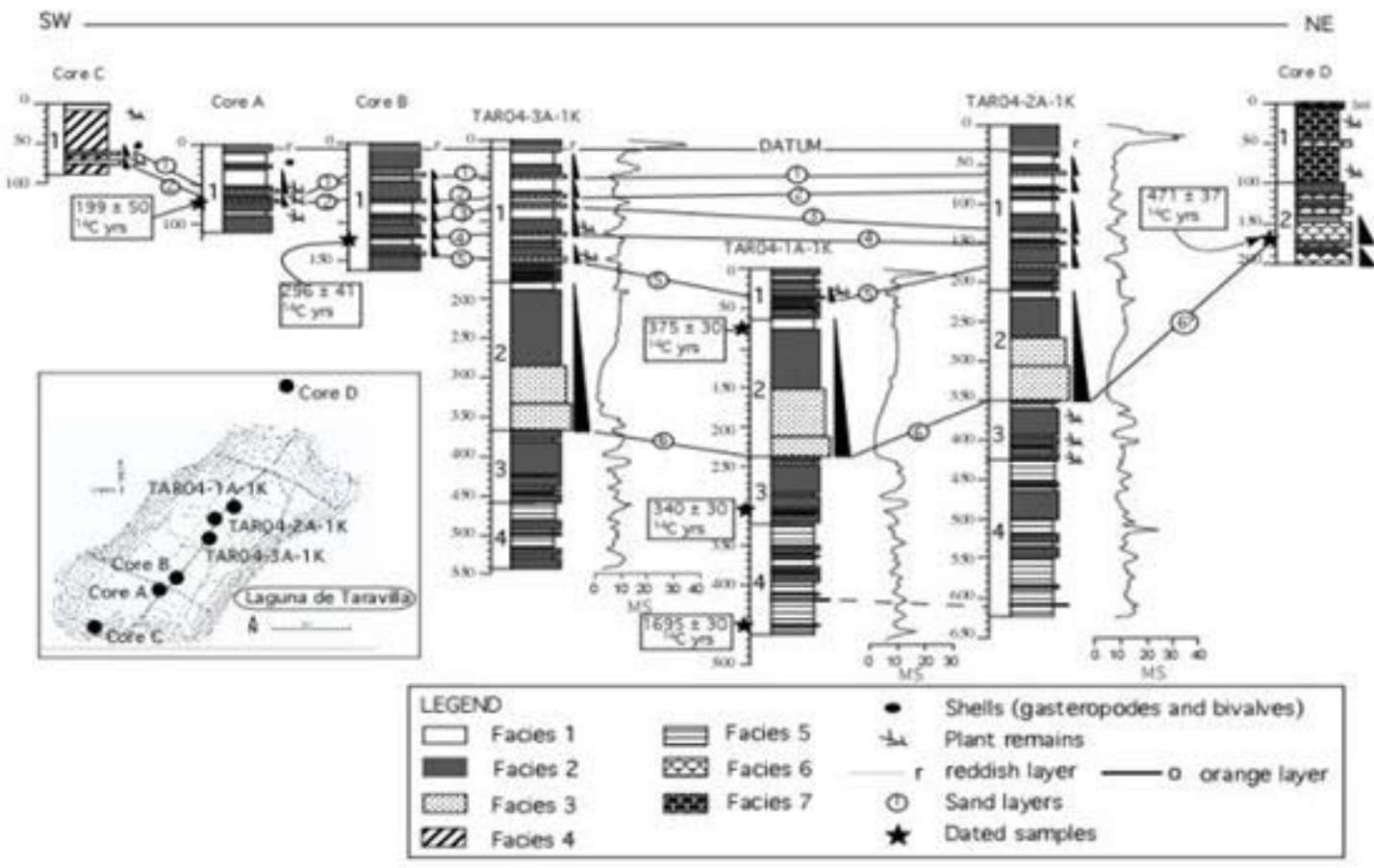

Figure 7 


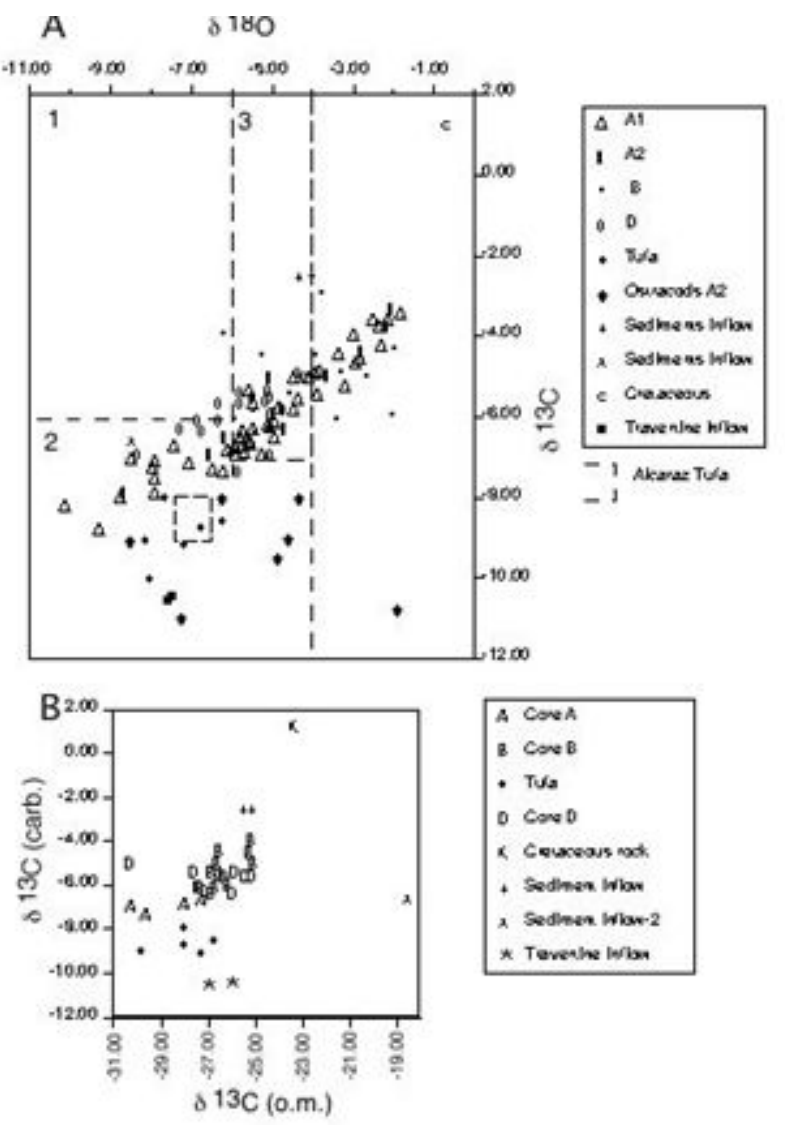

Figure 8 
Table captions

Table 1. Radiocarbon dating of Taravilla cores and travertines. $A A=$ Arizona laboratory; Poz $=$ Poznan Radiocarbon Laboratory, Poland. See text for explanation about calibration procedures.

Table 2. ${ }^{230}$ Th dating results. The error is $2 \sigma$ error. $\lambda_{230}=9.1577 \times 10^{-6} \mathrm{y}^{-1}, \lambda_{234}=2.8263 \times 10^{-6} \mathrm{y}^{-1}, \lambda_{238}=$ $1.55125 \times 10^{-10} \mathrm{y}^{-1} . * \delta^{234} \mathrm{U}=\left(\left[{ }^{234} \mathrm{U} /{ }^{238} \mathrm{U}\right]_{\text {activity }}-1\right) \times 1000 .{ }^{* *} \delta^{234} \mathrm{U}_{\text {initial }}$ was calculated based on ${ }^{230} \mathrm{Th}$ age $(\mathrm{T})$, i.e., $\delta^{234} U_{\text {initial }}=\delta^{234} U_{\text {measured }} \times \mathrm{e}^{\lambda 234 \times \mathrm{T}}$. Corrected ${ }^{230} \mathrm{Th}$ ages assume the initial ${ }^{230} \mathrm{Th} /{ }^{232} \mathrm{Th}$ atomic ratio of $4.4 \pm 2.2$ $\times 10^{-6}$. Those are the values for a material at secular equilibrium, with the crustal ${ }^{232} \mathrm{Th} /{ }^{238} \mathrm{U}$ value of 3.8 . The errors are arbitrarily assumed to be $50 \%$.

Table 3. Sedimentary facies in the Taravilla Lake cores. 
Table 1. Radiocarbon dating of Taravilla cores and travertines. $A A=$ Arizona laboratory; Poz $=$ Poznan Radiocarbon Laboratory, Poland. See text for explanation about calibration procedures.

\begin{tabular}{ccccccc}
$\begin{array}{c}\text { Sediment } \\
\text { core }\end{array}$ & Lab code & $\begin{array}{c}\text { Sample } \\
\text { depth }\end{array}$ & Material & $\begin{array}{c}{ }^{14} \text { C age } \\
(\text { yr BP })\end{array}$ & $\begin{array}{c}\text { Age error } \\
(y r)\end{array}$ & $\begin{array}{c}\text { Calibrated age } \\
(\text { cal yr BP })(2 \sigma)\end{array}$ \\
\hline A1 & AA48630 & 45 & Wood & 466 & 41 & $438-555$ \\
A2 & AA48628 & 70 & Wood & 199 & 50 & $59-234$ \\
B & AA48629 & 120 & Wood & 296 & 41 & $286-476$ \\
D & AA47854 & 170 & Wood & 471 & 37 & $471-549$ \\
Travertine & AA47856 & - & Wood & 192 & 47 & $143-217$ \\
TAR04-1A & Poz-9892 & 73 & Wood & 375 & 30 & $435-497$ \\
TAR04-1A & Poz-9809 & 310 & Wood & 340 & 30 & $311-480$ \\
TAR04-1A & Poz-12366 & 455 & Bulk sediment & 1695 & 30 & $1534-1636$
\end{tabular}


Table 2.. ${ }^{230}$ Th dating results. The error is $2 \sigma$ error. $\lambda_{230}=9.1577 \times 10^{-6} \mathrm{y}^{-1}, \lambda_{234}=2.8263 \times 10^{-6} \mathrm{y}^{-1}, \lambda_{238}=1.55125 \times 10^{-10} \mathrm{y}^{-1} . * \delta^{234} \mathrm{U}=\left({ }^{234} \mathrm{U} /^{238} \mathrm{U}\right]_{\text {activity }}-$ 1) $\times 1000$. ${ }^{* *} \delta^{234} U_{\text {initial }}$ was calculated based on ${ }^{230} \mathrm{Th}$ age $(\mathrm{T})$, i.e., $\delta^{234} \mathrm{U}_{\text {initial }}=\delta^{234} \mathrm{U}_{\text {measured }} \times \mathrm{e}^{\lambda 234 \times \mathrm{T}}$. Corrected ${ }^{230} \mathrm{Th}$ ages assume the initial ${ }^{230} \mathrm{Th} /{ }^{232} \mathrm{Th}$ atomic ratio of $4.4 \pm 2.2 \times 10^{-6}$. Those are the values for a material at secular equilibrium, with the crustal ${ }^{232} \mathrm{Th} /{ }^{238} \mathrm{U}$ value of 3.8. The errors are arbitrarily assumed to be $50 \%$.

\begin{tabular}{|c|c|c|c|c|c|c|c|c|c|}
\hline Tufa & Sample & $\begin{array}{l}{ }^{238} \mathrm{U} \\
\text { (ppb) }\end{array}$ & $\begin{array}{l}{ }^{232} \mathrm{Th} \\
\text { (ppb) }\end{array}$ & $\begin{array}{c}\delta^{234} U^{*} \\
\text { (measured) }\end{array}$ & $\begin{array}{c}{ }^{230} \mathrm{Th} /{ }^{232} \mathrm{Th} \\
\text { (activity) }\end{array}$ & $\begin{array}{c}{ }^{230} \mathrm{Th} /{ }^{238} \mathrm{U} \\
\text { (activity) }\end{array}$ & $\begin{array}{l}{ }^{230} \mathrm{Th} \text { Age (ka) } \\
\text { (uncorrected) }\end{array}$ & $\begin{array}{l}{ }^{230} \mathrm{Th} \text { Age (Ka) } \\
\text { (corrected) }\end{array}$ & $\begin{array}{l}\delta^{234} U_{\text {Initiali }^{* *}} \\
\text { (corrected) }\end{array}$ \\
\hline Barrage & Top, massive & $239.2 \pm 0.7$ & $752 \pm 10$ & $66.3 \pm 4.0$ & $5.5 \pm 0.2$ & $1.043 \pm 0.036$ & & & \\
\hline Barrage & $\begin{array}{c}\text { Top, } \\
\text { laminated }\end{array}$ & $126.8 \pm 0.3$ & $54.2 \pm 0.5$ & $323.2 \pm 2.9$ & $8.0 \pm 0.3$ & $0.2078 \pm 0.0074$ & $18.5 \pm 0.7$ & $8.8 \pm 5.2$ & $331 \pm 6$ \\
\hline Barrage & $\begin{array}{l}\text { Middle, } \\
\text { laminated }\end{array}$ & $110.7 \pm 0.3$ & $42.7 \pm 0.3$ & $321.6 \pm 3.9$ & $7.7 \pm 0.3$ & $0.1798 \pm 0.0059$ & $15.9 \pm 0.6$ & $7.1 \pm 4.6$ & $328 \pm 6$ \\
\hline Barrage & $\begin{array}{l}\text { Base, } \\
\text { massive }\end{array}$ & $266 \pm 1$ & $639 \pm 16$ & $63.9 \pm 3.7$ & $4.7 \pm 0.3$ & $0.682 \pm 0.040$ & $110 \pm 11$ & $11+61 /-11$ & $66 \pm 13$ \\
\hline Barrage & $\begin{array}{l}\text { Base, } \\
\text { laminated }\end{array}$ & $164.4 \pm 0.7$ & $97.4 \pm 0.9$ & $256.7 \pm 3.9$ & $6.6 \pm 0.2$ & $0.2376 \pm 0.0079$ & $22.7 \pm 8.4$ & $8.2+7.6 /-8.2$ & $263 \pm 7$ \\
\hline $\begin{array}{l}\text { Springline } \\
\text { perched tufa }\end{array}$ & Stromatolite & $88.9 \pm 0.2$ & $16.46 \pm 0.09$ & $267.3 \pm 1.7$ & $85.8 \pm 0.8$ & $0.9626 \pm 0.0082$ & $143.7 \pm 2.4$ & $139.7 \pm 3.1$ & $397 \pm 4$ \\
\hline
\end{tabular}


Table 3. Sedimentary facies in Taravilla cores

Facies

\section{Lacustrine facies}

Facies 1: Massive, dark grey silty-sand to coarse sand

Facies 2: Massive to faintly laminated light grey carbonate silt

Facies 3: Massive to faintly laminated, dark grey carbonate silt and mud

Facies 4: Gastropod and charophyte-rich coarse silt and mud

Facies 5: Laminated light gray-yellowish silt

\section{Palustrine facies}

Facies 6: Massive, gravel, sand and silt

Facies 7: Massive, dark brown, organic-rich, peaty carbonate-rich silt

\section{Description and depositional environment}

Cm- to dm-thick beds, massive to faintly laminated, fining upward textures; abundant plant macrorest. Depositional subenvironment: Flood deposits in the inner areas of the lake.

$\mathrm{Cm}$ - to dm-thick layers, massive, variable amount of carbonate and organic matter

Depositional subenvironment: Deposition in the middle of the lake during open water circulation periods

$\mathrm{Cm}$ to dm-thick layers, faintly laminated, relatively higher organic matter and lower carbonate content. Relatively high magnetic susceptibility.

Depositional subenvironment: Deposition in the middle of the lake during periods of more restricted water circulation.

Cm- thick layers with abundant fossils and calcified Chara remains. Depositional subenvironment: Littoral lacustrine

Cm-thick layers, laminated, dominant carbonate composition.Relatively low magnetic susceptibility.

Depositional subenvironment: middle of the lake, low energy dominant oxic bottom conditions

Dm-thick fining upward sequences Depositional subenvironment: Alluvial-delta

Dm- thick beds alternating with some thin peat layers. Depositional subenvironment: Palustrine 